\title{
From petrographic analysis to stereomicroscopic characterisation: a geoarchaeological approach to identify quartzite artefacts in the Cantabrian Region
}

\author{
Alejandro Prieto ${ }^{1,2}$ - Iñaki Yusta ${ }^{3} \cdot$ Alvaro Arrizabalaga $^{2}$ \\ Received: 8 June 2019 / Accepted: 6 November 2019 / Published online: 14 January 2020 \\ (C) The Author(s) 2020
}

\begin{abstract}
Several isolated studies have tried to understand quartzite from an archaeological perspective by applying two different methodological approaches. The first one is based on non-destructive characterisation, aiming to understand human procurement and management of quartzite, without solid geoarchaeological criteria. The second characterised the material from archaeological sites using only petrographic or geochemical perspectives of a limited sample. Currently, both perspectives are unconnected, creating a methodological gap that needs to be solved to study the procurement and management of quartzite in greater depth. The present study, mainly methodological, will explore the gap between petrographic analysis and non-destructive characterisation. Doing so, we could fill this vacuum of information and generate a solid geoarchaeological basis to characterise not only a sample but complete assemblages. To this end, we analyse the lithic assemblages at El Arteu and El Habario, two Middle-Palaeolithic sites in the Cantabrian Region, northern Spain. We summarise the main results derived from petrographic analysis, but especially we will focus on non-destructive criteria to characterise the lithic surfaces of archaeological quartzite using stereoscope microscopy. This process allows us to understand the complete assemblage but also, through technological characterisation, understand the management of different quartzite petrogenetic types in both sites.
\end{abstract}

Keywords Lithic technology $\cdot$ Management of raw material $\cdot$ Quartzite $\cdot$ Petrology $\cdot$ Stereomicroscope $\cdot$ Geoarchaeology

\section{Introduction}

\section{Quartzite in archaeology}

The study of raw materials used for lithic implements is a well-known topic of research in prehistoric archaeology. Since the beginning of this scientific discipline, petrological description and classification of rocks transformed into

Electronic supplementary material The online version of this article (https://doi.org/10.1007/s12520-019-00981-7) contains supplementary material, which is available to authorized users.

Alejandro Prieto

alejandro.de.prieto@fau.de; alejandro.prieto@ehu.eus;

alejandropdd@gmail.com

1 Institute of Prehistory and Protohistory, Department of Classical World and Asian Cultures, Friederich-Alexander University of Erlangen-Nuremberg (FAU), Kochstr. 4/18.,

D-91054 Erlangen, Germany artefacts was carried out by the first prehistorians, such as Juan Villanova i Piera or Édouard Lartet (Pelayo López and Gonzalo Gutiérrez 2012). The characterisation of these raw materials has become more detailed and frequent since the 1950s through the use of classic petrological methodologies and because of increasing archaeologist interest in new perspectives to understand prehistoric societies (Polanyi 1957). Both perspectives converge in the characterisation of obsidian

2 Department of Geography, Prehistory and Archaeology, University of the Basque Country (UPV/EHU), Paseo de la Universidad, 5., 01006 Vitoria-Gasteiz, Spain

3 Department of Mineralogy and Petrology, University of the Basque Country (UPV/EHU), Barrio Sarrena s/n, 48940 Leioa, Biscay, Spain 
as the key raw material to trace incipient commercial routes in the Mediterranean in Recent Prehistory (Binns and McBryde 1969; Dixon et al. 1968). The interesting results, and also the methodologies generated, led to a significant increase in lithic raw material studies for the next two decades, focussed not only in the trade itself, but also in the areas where abiotic resources were extracted by prehistoric societies (Earle and Ericson 1977; Kowalski et al. 1972; Sieveking et al. 1972; Singer and Ericson 1977). In the 1980s and 1990s, raw material studies increased not only in number, but also in their geographic and chronological frameworks. To do so, different raw materials were analysed and, for Palaeolithic Archaeology in Europe, flint became the best and most widely characterised raw material (e.g. Demars 1980; Floss 1990; Geneste 1985; Luedtke 1979; Morala 1980; Séronie-Vivien and Séronie-Vivien 1987). At the same time, research focussed on economic and social dynamics through the techno-typological characterisation of lithic assemblages has increased our knowledge of the acquisition and management of flint (Andrefsky 1994; Roebroeks 1988; Turq 1996). All these elements create a better understanding on the economy created around raw materials and the complex management and catchment patterns followed by Palaeolithic societies.

Despite being the second most-often-used lithic raw material in the European Palaeolithic, quartzite has not received the same methodological development from geoarchaeological perspectives as flint or obsidian. This situation creates a lack of information and many biases in understanding the catchment and management strategies pursued by prehistoric societies. This is especially important in those areas where flint is not common or in ancient chronologies in areas where nonflint rocks are predominant. However, in recent years, quartzite from archaeological deposits has been studied from geoarchaeological perspectives by combining different destructive methodologies such as petrographic analysis and geochemical procedures (Blomme et al. 2012; Cnudde et al. 2013; Dalpra and Pitblado 2016; Pitblado et al., 2008, 2012; Prieto et al. 2019; Veldeman et al. 2012). These studies reflect the ambiguity of the term quartzite in archaeological literature, where it can refer to different geological origins, from clearly metamorphic to sedimentary. This prompts the need of petrography to exactly differentiate sedimentary orthoquartzite from metamorphic quartzites. Similar discrepancies between megascopic identification and laboratory analysis are also mentioned by petrologists, especially when quartzite is used as a field name (Howard 2005; Skolnick 1965).

Archaeological quartzites have also been studied by other specialists using non-destructive techniques. In the Cantabrian Region, several studies have attempted to study this material by its macroscopic characterisation without examining these rocks from detailed and curated geoarchaeological perspectives (e.g. Álvarez-Alonso et al. 2013; Castanedo 2001; Manzano et al. 2005; Sarabia 2000). These studies have proposed different procurement and management strategies for quartzite, mainly based on techno-typological analysis, but their conclusions are clearly biased by the lack of accuracy in their descriptions. Currently, both perspectives are unconnected, creating a methodological gap that needs to be solved for more in-depth studies of quartzite acquisition and management strategies, based on a solid geoarchaeological approach.

The goal of this methodological work is to explore the gap between destructive analysis, mainly petrographic study of thin sections, and non-destructive characterisation of quartzite. The information gap might be filled in this way and a solid geoarchaeological basis might be established to characterise not only a sample but complete quartzite assemblages. To this end, we have analysed the lithic collections from El Arteu and El Habario, two Middle-Palaeolithic sites situated in the Central part of the Cantabrian Region, northern Spain. We summarise the main results derived from the petrographic and geochemical characterisation of 18 samples recently published by our research group (Prieto et al. 2019), but especially, we will focus on non-destructive criteria to characterise the lithic surfaces of quartzites using stereoscope microscopy and descriptive characterisation. The diagenetic and metamorphic changes which modify the texture and structure of former sedimentary rocks, the grain size and its distribution, and the mineral component itself will be analysed in this research using both approaches. Therefore, the correlation between both techniques (destructive and non-destructive) is the main goal of this research. This process allows us to understand the complete assemblage but also, through technological characterisation, to understand the management of quartzite in both sites, taking into account production, usage and discard of this raw material (Roebroeks 1988; Turq et al. 2013). During the last two decades, several studies have contributed to the knowledge about lithic management strategies developed by Middle-Palaeolithic groups in the Cantabrian Region (e.g. Carrión et al. 2008; Gonzalez-Urquijo et al. 2005; Rios-Garaizar 2012). These researches accomplished not only a description of lithic assemblages using typological characterisation of retouched artefacts, but they also unveiled catchment mechanisms (Carrión and Baena 1999; Castanedo 2001; Manzano et al. 2005), technological procedures (Carrión 2002; Cuartero et al. 2015; Maillo 2007; Santamaría et al. 2010) or use practices (Rios-Garaizar 2010). These studies have opened new perspectives to discover a complex and varied economy from geographic, chronological and human standpoint. The research we present here shows not only the management of quartzite at these two Middle-Palaeolithic sites, but also the new wider perspectives this geoarchaeological study can open in archaeological practice (Dibble et al. 2017; Romagnoli et al. 2018). 


\section{Materials}

The sites of El Habario and El Arteu are located in the central part of the Cantabrian Region, in the northwestern part of Spain (Fig. 1). They are in the western part of the Autonomous Community of Cantabria. This area is a mountainous region and the sites are located in the basin of the River Deva and its tributaries, in the eastern foothills of the Picos de Europa. This area is characterised by a complex geology determined by the presence of two geological domains. The first one is the eastern part of the Cantabrian Zone, mainly composed by Carboniferous materials. Two main provinces can be distinguished, the Pisuerga-Carrión Province, to the South and the Picos de Europa and Ponga Province to the West and North. Both provinces also contain
Cambrian, Ordovician, Silurian and Devonian strata (Bastida 2004). The second one is the western part of the BasqueCantabrian Basin, in particular, the Navarro-Cantabrian sulcus, dominated by sedimentary Mesozoic rocks and small parts of Cenozoic material. Neogene and Quaternary deposits are represented too (Barnolas and Pujalte 2004). In this context, quartzite is characterised by multiple and different environments: as outcrop (quartz arenites), generally related to the older strata; as pebbles and blocks inside carboniferous conglomerates; and as pebbles in fluvial quaternary deposits.

El Habario and El Arteu assemblages have been attributed chrono-culturally to the Mousterian, with discoid reduction methods mostly in quartzite. They appear to form a network of sites together with El Esquilleu rock shelter (Baena et al. 2005, 2012; Carrión 2002; Carrión et al. 2008, 2013;

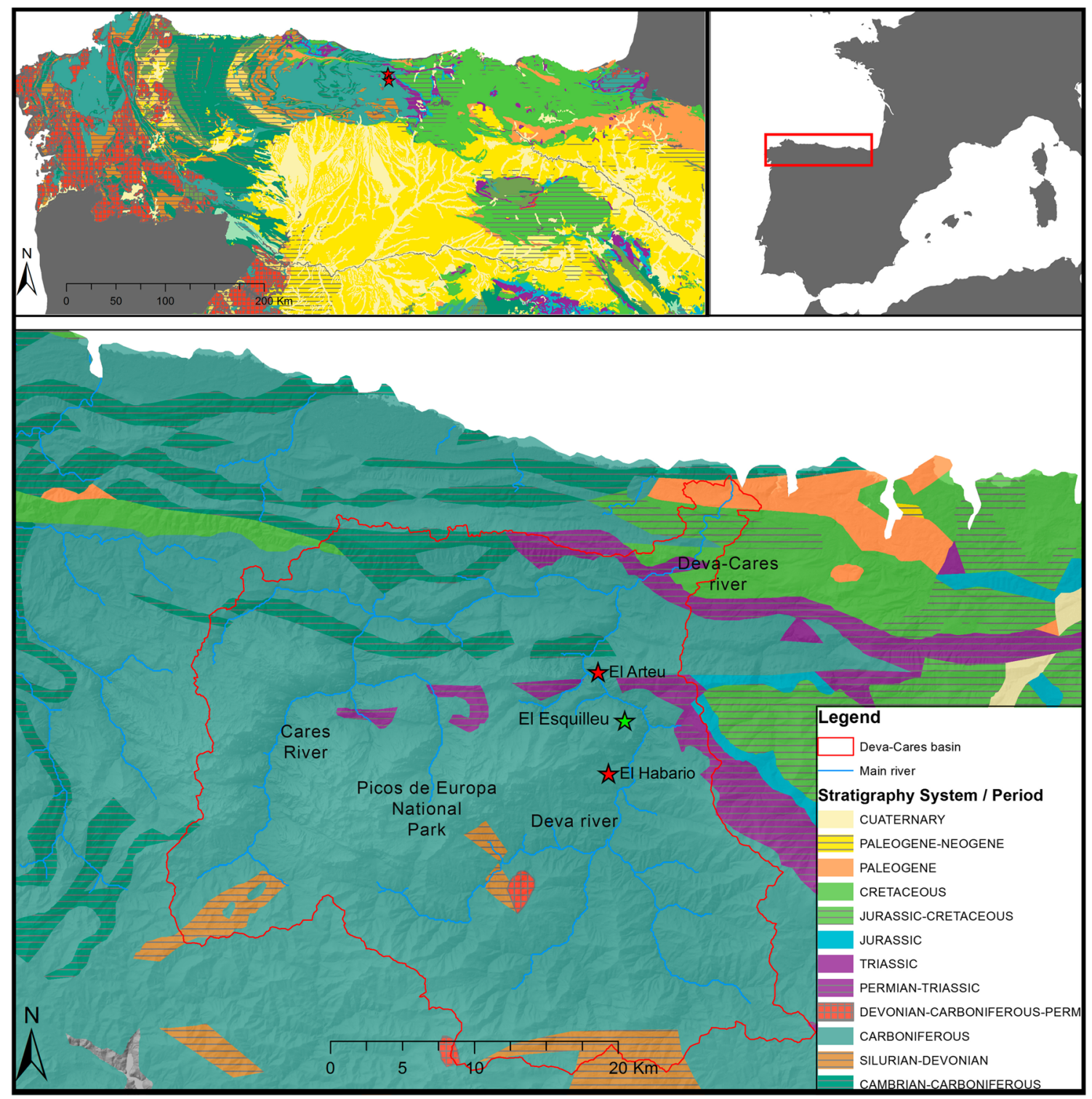

Fig. 1 Location of El Habario, El Arteu and the Deva-Cares Valley. Main chrono-lithological strata are displayed based on a 1:1.000.000 geological map (Álvaro et al. 1994) 
Manzano et al. 2005). The site of El Habario is an open-air site in a mountainous area, close to Carboniferous conglomerate bedrock units $(X=368.973 Y=4.784 .861$, 30T ETRS-1989). Two quite distinct levels were differentiated during excavation. The superficial level (El Habario A) is a sedimentary packet or level altered by bioturbation. The underlying, El Habario B, is a fertile level apparently in a primary position. The lithic assemblage was attributed to a single phase within the Mousterian and show techno-typological coherence. Despite there are no numerical dates, El Habario B was assimilated to the Middle Palaeolithic, mainly based on typological and technological studies (Carrión and Baena 1999, 2005). The latest researches concluded that the dominant lithic reduction model was based on hierarchical centripetal reduction processes aimed at flake production. All these reasons, as well as the proximity to the Remoña Conglomerates, identify this site as a workshop of quartzite, probably related with the central layers of the sequence of El Esquilleu and El Arteu. The collection analysed here comes from El Habario B and the number of pieces is 467 . All except three lithics are quartzites.

The archaeological site of El Arteu is situated in a small rock shelter in a rugged high-mountain area near the Deva and its confluence with the River Cares $(X=368.247 Y=$ 4.793.505, 30T ETRS1989). The artefacts were collected after they had fallen from a section, but they display industrial coherence. The lithic assemblage $(n=255)$ was attributed to a single phase within the Mousterian (Carrión 2002; Carrión et al. 2008). Technological characterisation of this assemblage showed that lithic reduction was done under Levallois or discoid lithic method and it was aimed at obtaining pointed flakes. The interpretation of El Arteu for hunting activities inside a complex residential model in the area was suggested by Baena et al. (2005). Radiolarite $(n=11)$, limestone (3), lutite (1) and hydrothermal quartz (1) are represented in addition to archaeological quartzite $(n=237)$.

The assemblages studied here are deposited in the Museum of Prehistory and Archaeology of Cantabria (MUPAC). Of the total of artefacts made in quartzite from El Habario (HA) and El Arteu (ATS), we sampled a set of representative pieces for thin section analysis $(n=17)$ and X-ray fluorescence analysis, as described in Prieto et al. (2019). We also select another sample from a Deva river beach. Petrographic analysis includes packing, texture and quartz grain feature description, also grain size characterisation based on image processing and, finally, mineral characterisation. The results point to a high variability of archaeological quartzite according to the genesis of the material. The 18 quartzites were classified into seven main types according to their petrogenesis as described by thin section, especially through the analysis of textures, packing and quartz grain features, and secondly by quartz grain size and morphology. The variability in mineral characterisation and geochemical composition was only used to understand similarities between quartzites at both sites, understanding them as cumulative features to the main types defined. The petrogenetic types used here are the following (Table 1): for sedimentary quartzites, clastic fabric with matrix or non-quartz cement quartz arenite (MA), clastic quartz arenite (CA), syntaxially overgrown orthoquartzite (OO) and sutured grain orthoquartzite (SO); and for truly metamorphic quartzites another three types depending on the textural changes on quartz grains: bulging recrystallised quartzite (BQ), subgrain rotation recrystallised quartzite (RQ) and grain boundary migration recrystallised quartzite (MQ). This classification is based on the geological work of several researchers (Bastida 1982; Folk 1974; Howard 2005; Wilson 1973). In order to readily identify and manage in large databases, a two-letter code is used for every petrogenetic type. When possible, we try to relate the first letter with a relevant microtextural feature of the rock, e.g. presence of matrix (M) or syntaxially quartz overgrowths $(\mathrm{O})$; whereas the second capital letter applies to the specific rock type, precisely sandstones are labelled as arenites (A) or orthoquartzite $(\mathrm{O})$, and metamorphic quartzites with the letter $(\mathrm{Q})$.

\section{Methodology}

\section{Features to characterise, analysis to understand}

We first studied 18 selected hand samples that were used for thin-section preparation to describe their textural and grain features. Once they were described using a stereomicroscope and the information was related with that obtained by standard petrographic methods on an optical microscope, we described the other 687 quartzite pieces from the complete assemblage.

We also described these pieces according to the basic techno-typological characterisation based on Analytical Typology (Laplace 1972). We used the proposal made by Maite García-Rojas to understand technological products (García-Rojas 2010, 2014). First, we classified lithic implements attending to three categories: (a) cores, characterised by the presence of one or more knapping surfaces and one or more striking platforms; (b) knapping products, characterised by the presence of a ventral and a dorsal surface and the presence of a butt of striking platform; and (c) chunk, material that could not be classified in the two previous categories due to the lack of criteria. Cores are classified as discoid, levallois, irregular or core on flakes attending to their features and morphology (Fig. 2). Knapping products are classified as blanks, in case there is only one plane in the dorsal surface (including flakes, blades and bladelets), or core preparation/rejuvenation products, a knapping product with presence of two different planes on its dorsal surface. One of these planes has a percussion platform while the other, a dorsal surface. This category includes core tables or core-trimming elements. Finally, blanks are classified into four categories attending to 
Table 1 Summarised characterisation of thin section from the samples of El Arteu and El Habario, derived from Prieto et al. 2019. ++ is for higher presence

\begin{tabular}{|c|c|c|c|c|c|}
\hline Petrogenetic type & Texture & Packing & Quartz grain features & Grain size, morphology and orientation & Samples \\
\hline $\begin{array}{l}\text { Matrix or cemented } \\
\text { Quartz arenite } \\
\text { MA }\end{array}$ & Clastic & Floating Punctual & $\begin{array}{l}\text { Detrital quartz grains, abundant } \\
\text { matrix and/non-quartz cement }\end{array}$ & $\begin{array}{l}\text { Variable quartz grain size and } \\
\text { morphology, preferential orientation? }\end{array}$ & Geological origin \\
\hline $\begin{array}{l}\text { Clastic rained quartz } \\
\text { arenite } \\
\text { CA }\end{array}$ & Clastic & $\begin{array}{l}\text { Tangential } \\
\text { Complete }\end{array}$ & $\begin{array}{l}\text { Detrital grains, concave-convex } \\
\text { boundaries }\end{array}$ & $\begin{array}{l}\text { Variable quartz grain size and } \\
\text { morphology, preferential orientation? }\end{array}$ & $\begin{array}{l}\text { ATS-002 } \\
\text { ATS-151 }\end{array}$ \\
\hline $\begin{array}{l}\text { Syntaxially } \\
\text { overgrown } \\
\text { Ortho-quartzite } \\
\text { OO }\end{array}$ & Clastic & Tangent-Complete & $\begin{array}{l}\text { Syntaxially overgrowth, } \\
\text { concave-convex boundaries, un- } \\
\text { dulatory extinction }\end{array}$ & $\begin{array}{l}\text { Bigger quartz grains } \\
\text { Homogeneous distribution } \\
\text { Well-rounded grains }\end{array}$ & $\begin{array}{l}\text { ATS-001 } \\
\text { ATS-007 } \\
\text { ATS-023 } \\
\text { ATS-308 } \\
\text { HA-5855 }\end{array}$ \\
\hline $\begin{array}{l}\text { Sutured grain } \\
\text { Ortho-quartzite } \\
\text { SO }\end{array}$ & Clastic & $\begin{array}{l}\text { Complete } \\
\text { Suturated }\end{array}$ & $\begin{array}{l}\text { Suturated quartz grains } \\
\text { Undulatory extinction } \\
\text { Deformation lamellae }\end{array}$ & $\begin{array}{l}\text { Smaller quartz grains } \\
\text { Preferential orientation } \\
\text { Irregular quartz grains }\end{array}$ & $\begin{array}{l}\text { ATS-190 } \\
\text { ATS-302 } \\
\text { ATS-310 } \\
\text { HA-5827 }\end{array}$ \\
\hline $\begin{array}{l}\text { Bulging recrystallised } \\
\text { Quartzite } \\
\text { BQ }\end{array}$ & Mortar & Suturated & $\begin{array}{l}\text { Recrystallised quartz grains } \\
\text { Suturated quartz grains } \\
\text { Deformation lamellae }\end{array}$ & $\begin{array}{l}\text { Two mode size and morphological } \\
\text { distribution: Small \& rounded + bigger } \\
\text { and irregular grains } \\
\text { Preferential orientation }\end{array}$ & $\begin{array}{l}\text { ATS-016 } \\
\text { ATS-072 } \\
\text { HA-5847 } \\
\text { HA-5848 }\end{array}$ \\
\hline $\begin{array}{l}\text { Subgrain rotation } \\
\text { recrystallised } \\
\text { Quartzite } \\
\text { RQ }\end{array}$ & Mortar & Suturated & $\begin{array}{l}\text { Recrystallised quartz grains ++ } \\
\text { Suturated quartz grains } \\
\text { Deformation lamellae }\end{array}$ & $\begin{array}{l}\text { Two modes on grain morphology } \\
\text { One mode and negative kurtosis size } \\
\text { distribution } \\
\text { Preferential orientation }\end{array}$ & ATS-195 \\
\hline $\begin{array}{l}\text { Grain boundary } \\
\text { migration } \\
\text { recrystallised } \\
\text { Quartzite } \\
\text { MQ }\end{array}$ & $\begin{array}{l}\text { Clastic/ } \\
\text { foam }\end{array}$ & Suturated & $\begin{array}{l}\text { Suturated gran limits } \\
\text { Deformation } \\
\text { lamellae }++\end{array}$ & $\begin{array}{l}\text { One mode distribution with negative } \\
\text { kurtosis for size and morphology }\end{array}$ & HA-5842 \\
\hline
\end{tabular}

Fig. 2 Technological products identified at both sites: a levallois core (El Habario), b irregular core (El Habario), c discoidal core (El Habario) and $\mathbf{d}$ core on flake core (El Arteu) a
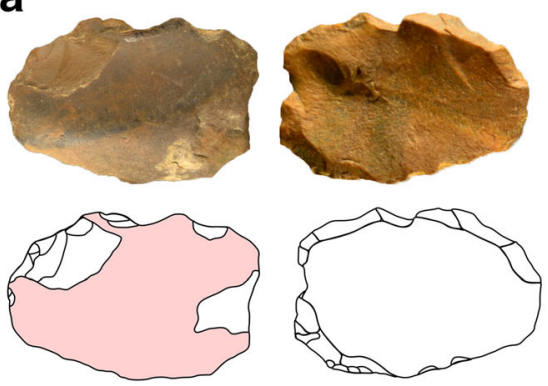

$\overline{3 \mathrm{~cm}}$

C
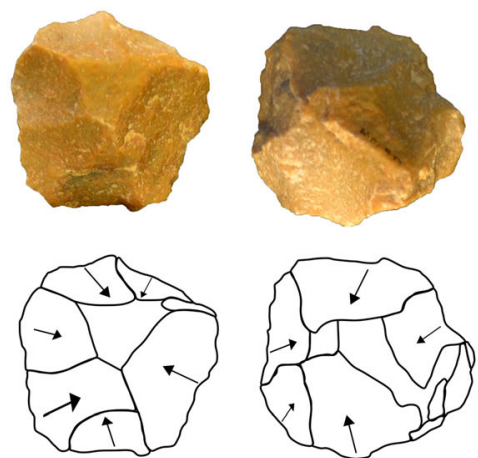

$3 \mathrm{~cm}$ b
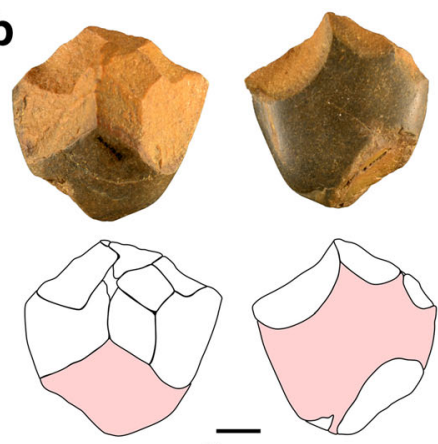

$3 \mathrm{~cm}$

d
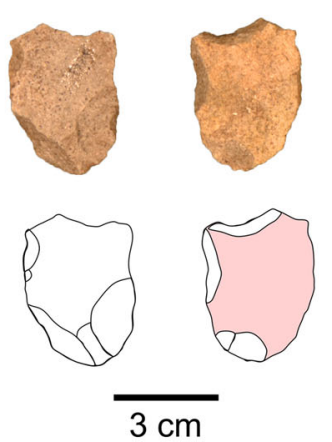
the quantity of scars on the dorsal surface. In addition, they are classified into another four categories attending to the quantity of cortex on dorsal surfaces (Fig. 3). Retouch is analysed as an accumulative feature on technological products, and we have only counted the number of primary types on each piece (Fernández-Eraso and García-Rojas 2013; Laplace 1987). Finally, the metrical characterisation of the pieces was done using their weight.

The non-destructive petrological characterisation of quartzites in both assemblages was based on four different scales of observation. The first one is based on naked-eye description. The second one, uses two $\times 10$ and $\times 20$ hand magnifiers, a stereomicroscope and the Dino-Lite digital microscope to the same magnifications. The third scale employs $\times 50$ magnification provided by the Dino-Lite digital microscope and by stereomicroscopes. The fourth applies $\times 250$ magnification with the first instrument. Most of the pieces were photographed in a flat position to $\times 50$ and $\times 250$ magnification to create a library of reference pictures. We preferentially used Dino-Lite model AD7013MZT with polarized light to eliminate most of the surface lustre. The microscope was handled with the MS35B vertical stand. We used the software Dino-Capture 2.0. The stereomicroscope used was the Nikon SMZ800, with up to $\times 120$ magnification. Nondestructive rock characterization is based on (a) qualitative characterisation of texture and quartz grain features, (b) quantitative-qualitative characterisation of quartz grain size and orientation and (c) characterisation of non-quartz elements (Fig. 4).

\section{Qualitative characterisation of texture, packing and quartz grain features}

We qualitatively systematised lustre to the naked eye on the surface of quartzites in four categories: (a) no lustre, (b) low lustre, (c) medium lustre and (d) high lustre.

Density of surface micro-cracks/chips in the surface of quartzite to naked eye. These areas are characterised as lighter and sparkling elements with scale morphology that appears on the surface of quartzites (Fig. 5). We systematised their presence using the following criteria: (a) absence, (b) small, (c) medium or (d) high presence of micro-cracks.

Quartz grain boundaries definition/recognisability was defined using a surface section of approximately $1.6 \times$ $1.3 \mathrm{~mm}$ at $\times 250$ magnification as (a) very easy, when at least 25 quartz grains were recognisable; (b) easy, when between 15 and 25 quartz grains were observable; (c) difficult, when between 5 and 15 quartz grains could be recognised; and (d) impossible, when fewer than 5 quartz grains were recognisable.

We distinguished five different types of packing in hand specimens according to the categories used for thin section and the following criteria (Fig. 6):
Fig. 3 Technological products identified at both sites: a blank without scars and more than $66 \%$ of cortex on it (El Arteu), b blank with one negative scar and more than $66 \%$ of cortex on it (El Habario), $\mathbf{c}$ blank with two negative scars with less than $33 \%$ of cortex on it (El Arteu), d blank with three or more negative scars and cortex between 33 and $66 \%$ of dorsal surface (El Arteu), e core preparation/rejuvenation product (El Arteu) and $\mathbf{f}$ chunk (El Arteu) a
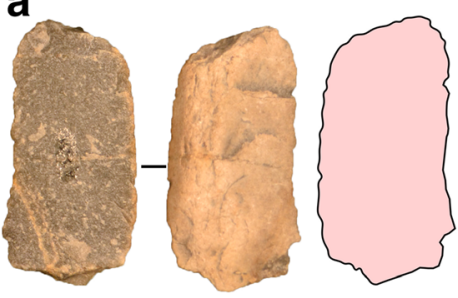

b

C

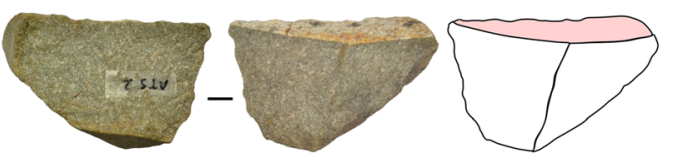

e
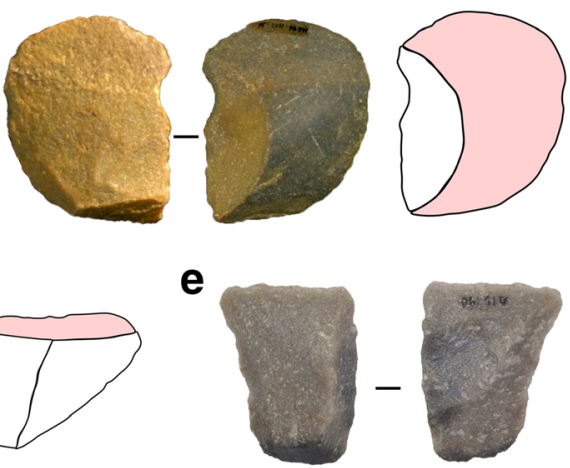

d

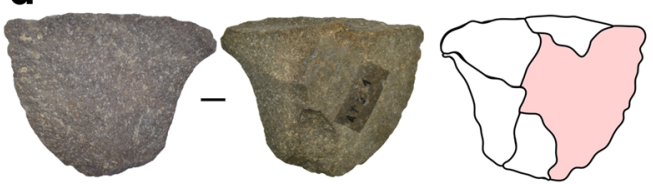

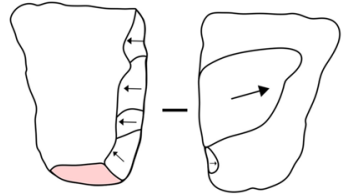

f

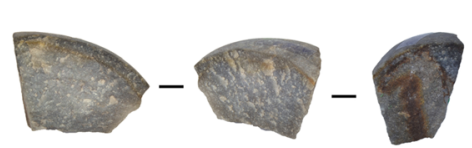

$3 \mathrm{~cm}$ 
Fig. 4 Non-destructive characterisation scheme, showing the features observed in different scales of observation

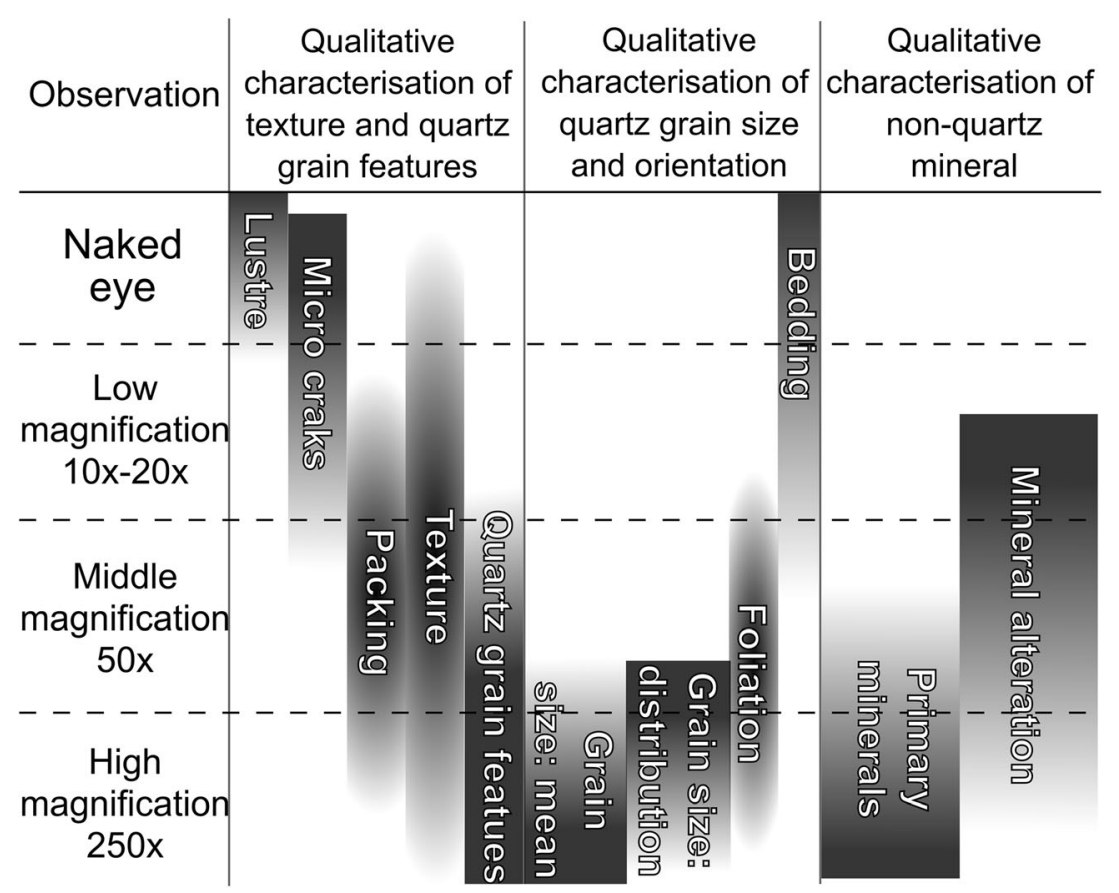

1. Floating, if the quartz grains are separated one from each other by matrix or cement.

2. Punctual or isolated, when the quartz grains are one near another and the contacts between them are restricted to single points. At ranges between $\times 50$ and $\times 250$, the grains are closer to each other, but contacts are very small or absent.

3. Tangential, in case the grains are joined together, but cement is still present. At $\times 50-\times 250$ magnification, the cement is restricted to a thin layer between the limits of the quartz grains.

4. Complete, where there is a very small content of cement or matrix and the grains create an almost complete texture. Matrix or cement is almost absent, limited to few accumulations in small confined areas between grains. They are delimited by very weak, fine and straight contours.

5. Suturated, when the limits between grains generate a complete and deformed texture. Matrix or cement is restricted
Fig. 5 Surface micro-cracks on the lithic artefact ATS-190. To the naked eye, white, irregular and lighter superficial areas are identified. At $\times 20, \times 50$ and $\times$ 250 magnification surface microcracks are also present and recognised by similar features
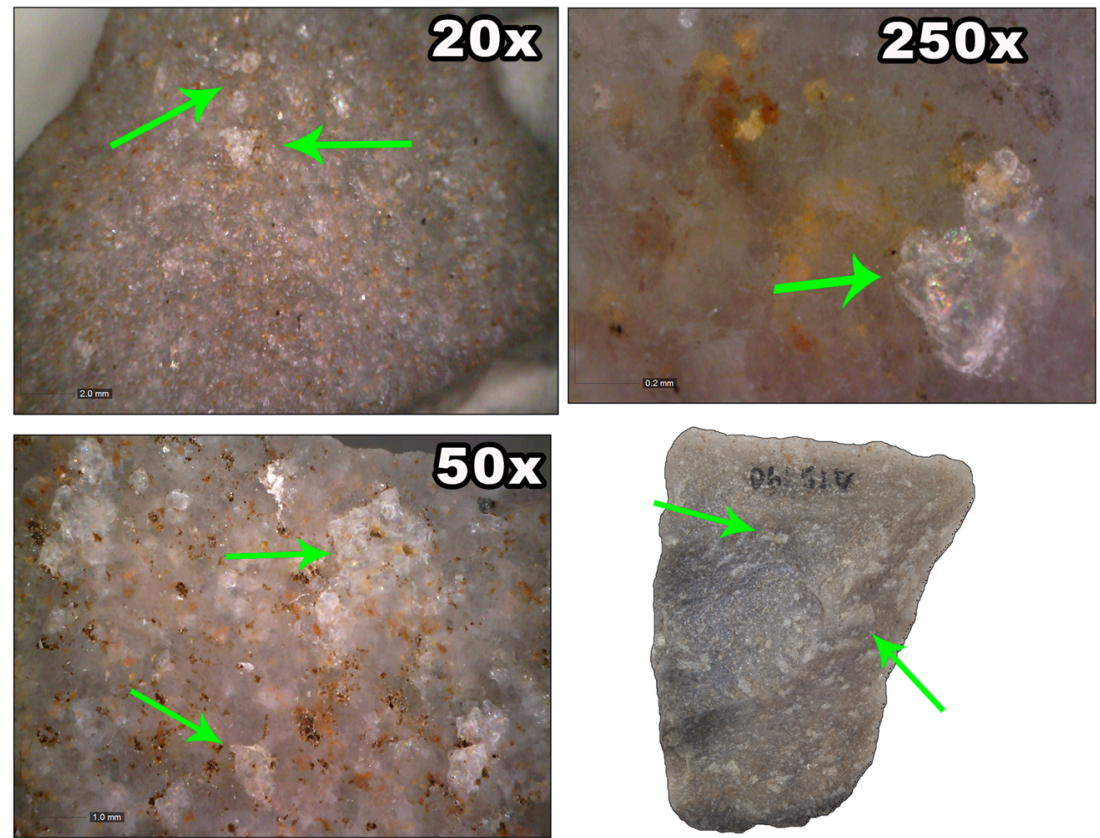


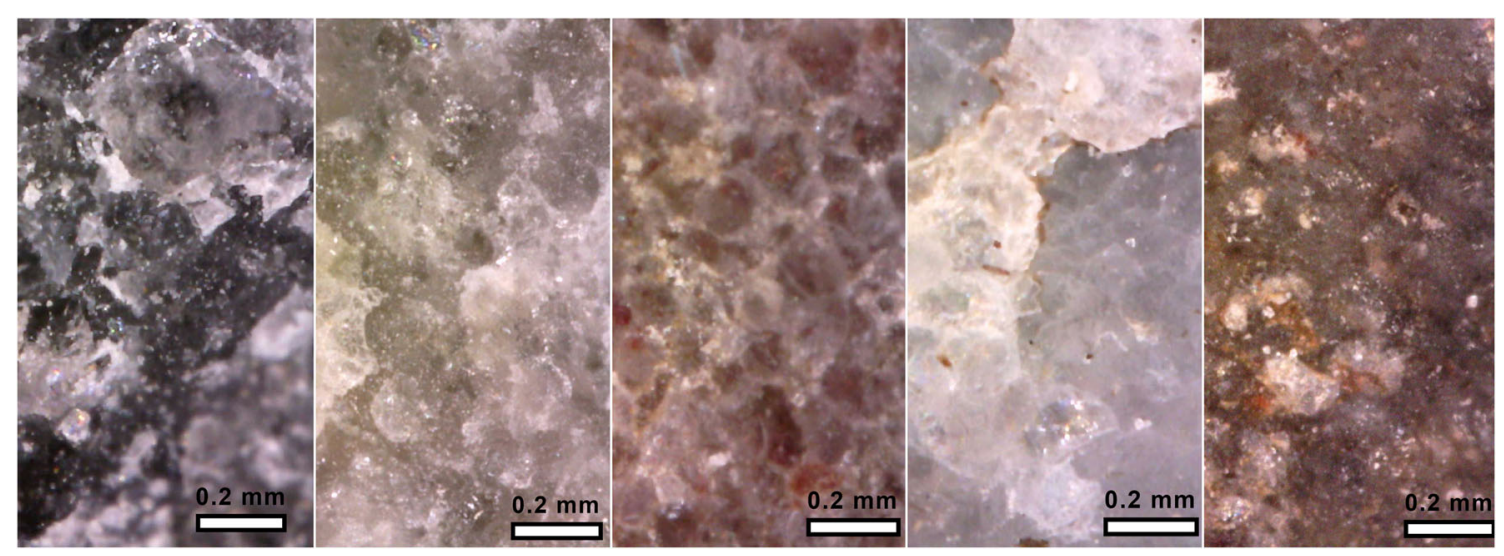

Fig. 6 Microphotographs of the surface of five different archaeological quartzites at 250x magnification attending to the packing criteria. From left to right Rb_01 (River beach) (floating), ATS-002 (punctual), ATS-151 (tangential), ATS007 (complete) and ATS-072 (suturated)

to small points on quartz limits, as in the previous packing type.

We distinguished six different types of texture, not only attending to the perception of the surface relief or the feel (touch) of the quartzite surface, but also using criteria observable by stereomicroscope. Texture categories are the following:

a. Saccharoid texture is defined by the generalised presence of matrix or a carbonate cement on the surface of the samples. The touch is granular and sandy and it is usually heterogeneously coloured to the naked eye. At low magnification, slopes and rough relief are appreciated. At middle magnification, it is possible to observe the presence of isolated to tangential quartz grains surrounded by large amounts of matrix and secondary diagenetic cement, creating a rough relief. Some quartz grains can sparkle, but the lustre is not homogeneously distributed. At high magnification, quartz grains tend to be isolated and, again surrounded by matrix, generally as the sum of small specks that cover the surface of quartz and other mineral grains (Fig. 7).

b. Granular texture is defined by a clear granular touch on the surface of the sample. The quantity of matrix or cement is reduced and its presence is restricted to small areas or the surroundings of the edges of the grains. To the naked eye, it generally shows a heterogeneous colour distribution. At low magnification, softly rough to flat relief is appreciated. At middle magnification, it is possible to recognise quartz grains and some of them can sparkle, but lustre is not homogenous. At high magnification, grains of these rocks are also recognisable and small quantities of cement or matrix (mainly formed by the sum of small specks) fill the small empty areas between quartz grains (Fig. 7). c. Compact and grainy texture is defined by the presence of a very soft granulated touch on the surface of the sample. There is no presence of matrix or cement. To the naked eye, the colour is more homogeneous and micro-cracks are recognisable. At low magnification, the relief is gentler than that in the previous texture and some of the surfaces show successive planes of squamous surfaces. At middle magnification, most of the grains are still recognisable, especially the lighter grains which show clear and curved outlines, although some parts of them cannot be appreciated. In a same way, at high magnification, grains are recognisable, especially those with thicker, brighter and curved outlines. Other grains or parts of the outlines are vague or diffused. The previously commented lighter grains are visible (Fig. 7).

d. Fine and grainy texture is defined by a smooth touch and a moderate lustre. In general, grains are difficult to observe completely. Although the touch is fine, small rough areas could be observed, mainly generated by the presence of secondary ferruginous, siliceous or carbonate precipitates or by the presence of joints. To the naked eye, colour is relatively homogeneous, except in micro-cracks, which are generally brighter. At low magnification, the relief is soft without roughness, although some surfaces of the quartzite show squamous surfaces. At middle magnifications, grains are hardly recognisable and there is a thin and bright lustre covering the surface of the rock. At high magnification, grains are almost unrecognisable and only some outlines can be appreciated. Small specks are visible on the outlines of the quartz grains and they seem to be on the same level as the rest of the surface, covered by the previously mentioned thin and bright lustre (Fig. 8).

e. Fine texture is defined by a really smooth touch and a shiny/brilliant lustre. In general, grains cannot be observed and only some small relicts from their outlines are seen. The touch is very fine and, as in the previous 
Fig. 7 Microphotograph of the surface of three quartzites. On the left, $\times 50$ magnification picture and, on the right, $\times 250$ magnification one. From top to bottom, ATS-164 possesses a saccharoid texture; ATS-080 exhibits granular texture; and, finally, ATS-304 represents compact and grainy texture
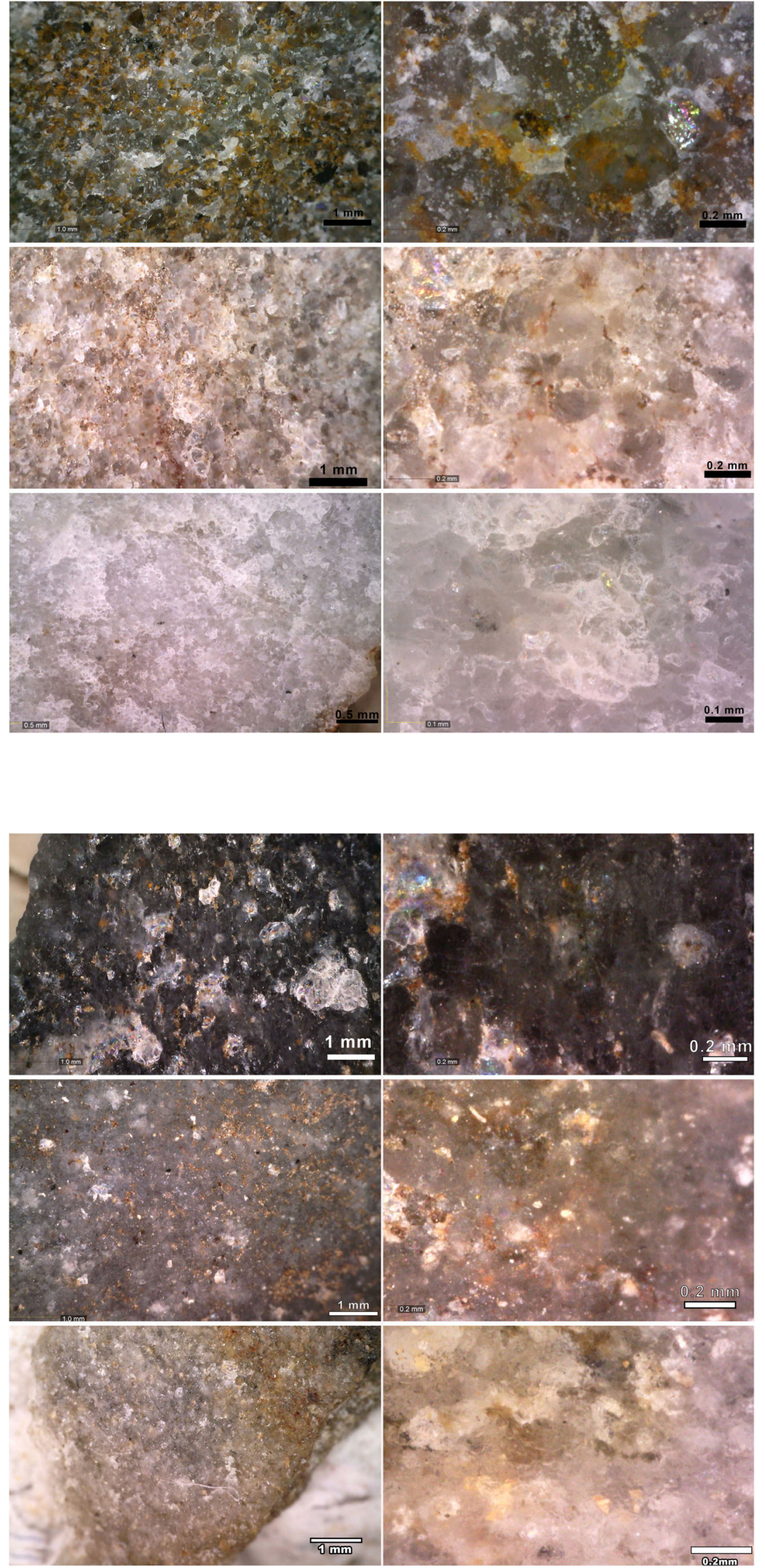

Fig. 8 Microphotograph of the surface of three quartzite pieces taken at $\times 50$ magnification (left) and at $\times 250$ magnification (right). From top to bottom, ATS079 shows fine and grainy texture; ATS-072 exhibits fine texture; and, finally, HA-5842 represents soapy texture 
texture, some areas can be rougher due to cement precipitations. To the naked eye, colour is homogenous and shows a high lustre. Micro-cracks are much more limited than those in the previous texture, although they are present. At low magnification, the relief is very soft and no rugosity is observed; neither is there a large quantity of squamous surfaces, which are reduced to very small areas. At middle magnification, no grains are recognisable and only small specks are visible. Thin and bright lustre is observed and it clearly covers the entire surface of the quartzite. At high magnification, no grain is observed and only small specks or associations of them are recognised on the surface, reduced to small areas (Fig. 8).

f. Soapy texture is quite similar to the preceding one. The touch is soapy, even smoother than that in the previous texture, and no grains are observed. To the naked eye, colour is really homogeneous, very bright, and microcracks are limited. At low magnification, the relief is plain and soft and there is almost no plain squamous surface. At middle magnifications, no grains are recognisable and neither are the small specks appreciated in the preceding texture. Previous thin and bright lustre is extended onto the entire surface of the quartzite. At high magnifications, only a few grains are recognisable, not by the outlines but by a small, thin and almost unrecognisable bulging that creates a wavy micro-relief. Hardly any small specks are appreciated (Fig. 8).

Quartz grain features were determined by applying morphological features of the border of the quartz grains. We reduced the variability of each quartzite to the two prevailing categories. These were:

1. Quartz grains with plain and angular limits (Fig. 9a).

2. Quartz grains with plain and rounded limits (Fig. 9b).

3. Quartz grains with ruffled and irregular limits generated by the effect of matrix or cement (Fig. 9c).

4. Quartz grains with appearance of regrowth of quartz syntaxial cement, recognisable by the partial or complete dual grain outline that creates a lighter, glossy and curved space between both lines, generally in concavo-convex lines between grains (Fig. 9d).

5. Quartz grains with ruffled, irregular and thin limits and surfaces with flat relief (Fig. 9e).

6. Quartz grains with no boundaries detected, where the limits are reduced to small alignments of specks or small saturated lines (Fig. 9f).
Fig. 9 Microphotograph of the surface of some quartzite pieces at $\times 250$ magnification. The main quartz grain features are a quartz grains with plain and angular limits (arrows on clear angular outlines of the quartz grains), from the sample ATS-089. b Quartz grains with plain and rounded limits, from sample HA5632. c Quartz grains with ruffled and irregular limits generated by the presence of matrix or cement, from sample ATS-339. d Appearance of regrowth of syntaxial quartz cement (arrow on syntaxial quartz cement in the direction of its growth), from sample ATS-308. e Quartz grains with ruffled irregular and thin limits on flat surface, from sample HA-5500. f Quartz grains with no apparent boundaries detected, reduced to small alignments of specks, from sample HA-5519
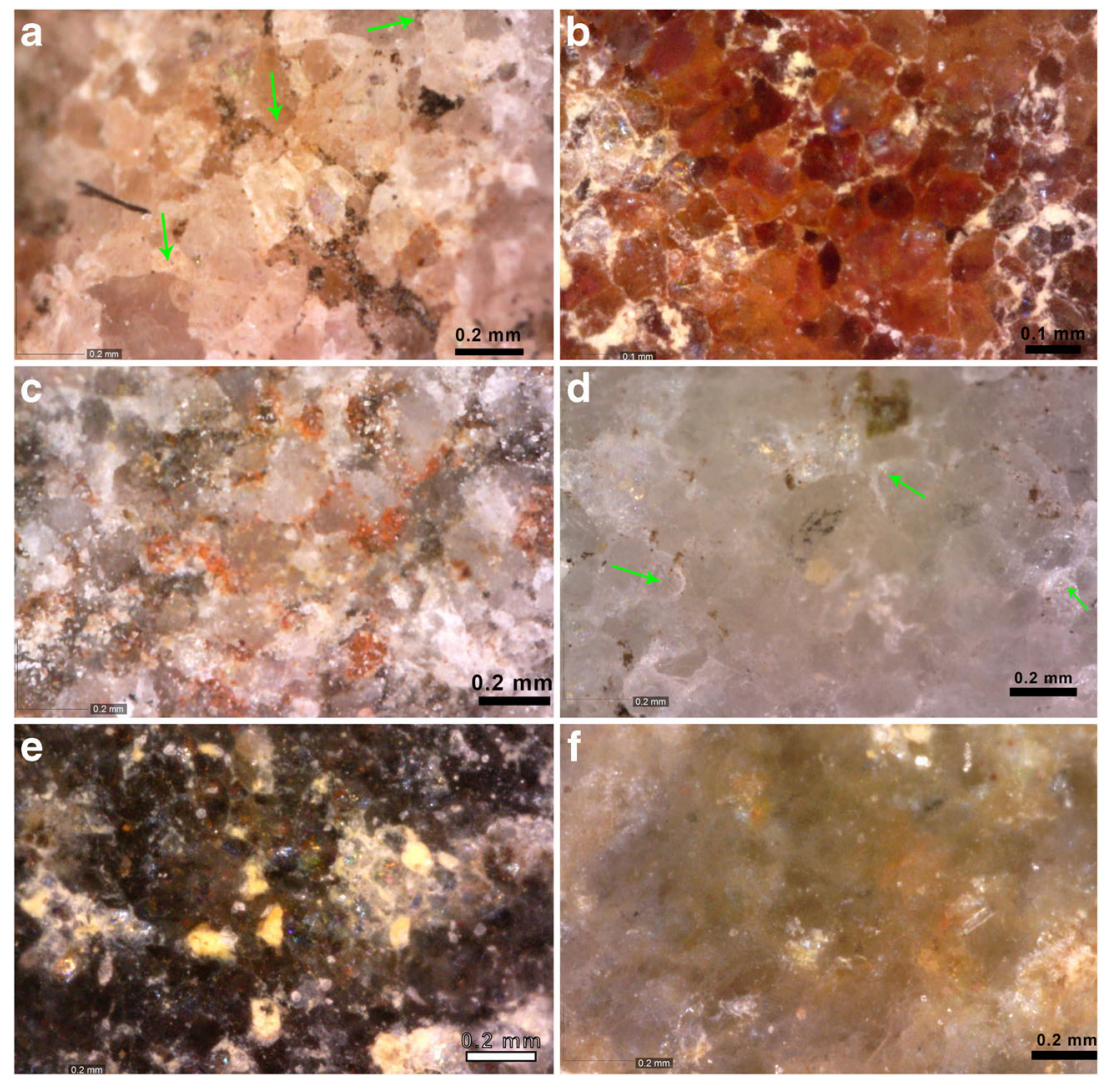


\section{Qualitative characterisation of quartz grain size and orientation}

As commented before, we tried to recognize in hand specimens the mineral and textural features observed in thin sections, as a way to link the information from destructive and non-destructive methodologies. Nevertheless, due to the lower resolution of stereomicroscopes and the restrictions imposed by the lack of polarizing light to properly recognize grain features, the amount of information generated, and especially the possibility of applying different techniques, here we measure quartz grain size using a qualitative scale. This allows us to analyse a large number of rock implements using only two criteria that systematise the grain size of quartzites.

On one hand, we determined mean grain size using $\times 50$ and $\times 250$ magnification, obtaining the approximate measurement of the secondary axis of the particles. The measurement was performed with the measuring mode provided by the software Dino-Capture 2.0. In general, the number of measured grains per sample is higher than 20. So we used three categories, based on the Udden-Wentworth scale (Wentworth 1922) and modified for their application to quartz grains according to the conclusion reached by Prieto et al. 2019: (a) Coarse quartz grain size, used for quartzites containing quartz grains bigger than fine sand (>0.25 mm); (b) medium quartz grain size, used for quartz grains between coarse silt and fine sand $(0.031$ to $0.25 \mathrm{~mm})$; and (c) fine quartz grain size, used for quartzites with grains smaller than coarse silt $(<0.062)$. For heterogeneous samples, the biggest grain determined was assigned as the size of the quartzite.
On the other hand, we completed the qualitative analysis of quartz grains by describing their sorting degree using the following categories: homogeneous, bimodal or heterogeneous quartz grain according to the size distribution.

We also noted the presence of bedding planes on the surface of quartzites, both to the naked eye and using low magnification, according to the following criteria: (a) absence of bedding, (b) non-clear bedding and (c) clear bedding.

Finally, we tried to recognize foliation features on at least one surface of the sample, although this is not an easy task in hand specimens of highly compact quartzites (Fig. 10).

\section{Qualitative characterisation of non-quartz mineral}

In addition to quartz, archaeological quartzites contain other minerals in very small proportions. Up to three of the most representative minor minerals were identified in every sample. The observed minerals are the following: as primary phases (a) white mica, (b) feldspars, (c) pyrite and (d) undetermined black minerals, and as alteration phases (e) Fe and/or Mn oxides (Fig. 11).

\section{Results}

\section{From petrographic analysis to binocular characterisation}

The groups and types established through petrographic analysis of thin sections were used for non-destructive characterisation of hand specimens by using similar qualitative criteria
Fig. 10 Microphotograph of the surface of two quartzite pieces at $\times 50$ and $\times 250$ magnification. On the left side, ATS-205 exhibits clear bedding of the surface with grains preferentially oriented and silica matrix filling the empty space between them. No grain is deformed. On the right side, sample HA-5847 shows clear foliation. It is easy to distinguish schistosity from bedding owing to the modification of quartz grains in the former, while in the latter no modification of quartz grains is observable (both observations at $\times 250$ magnification)
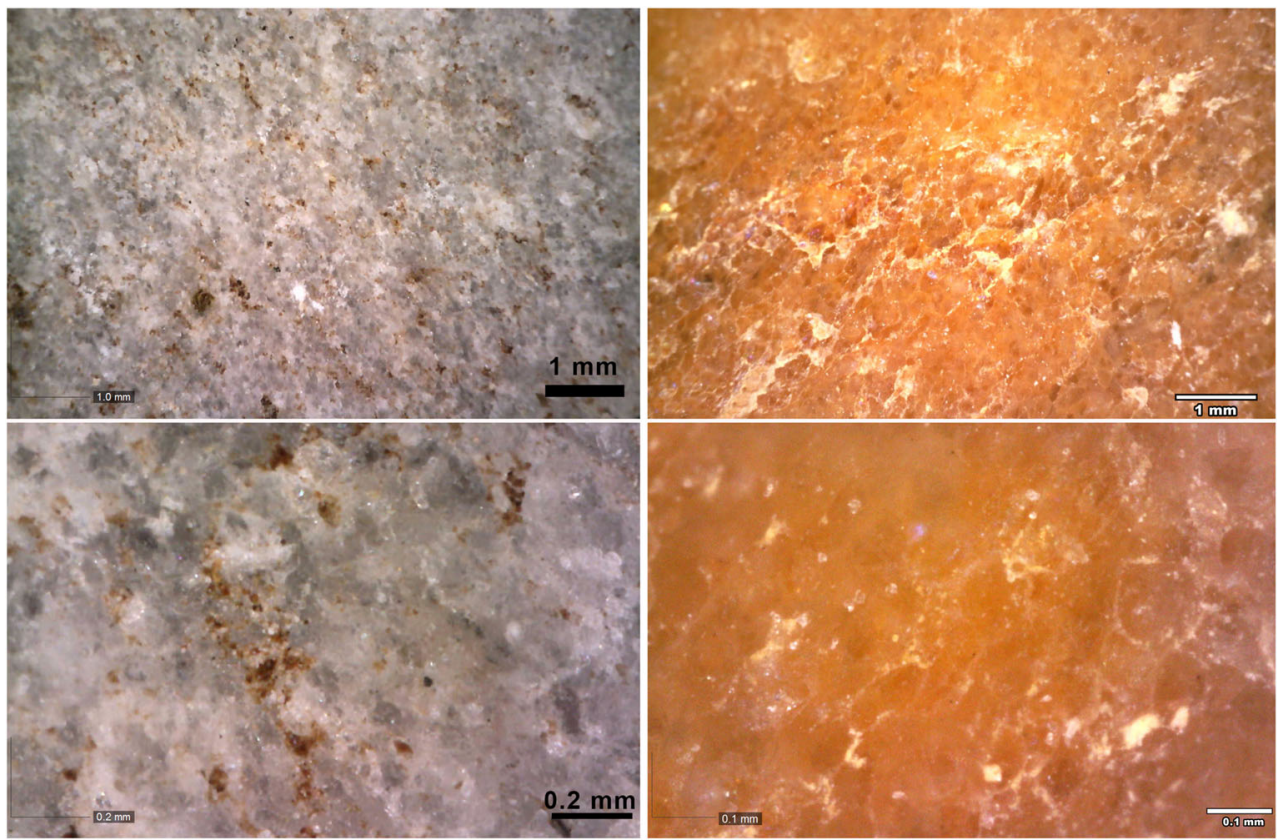
Fig. 11 Microphotograph of the surface of six quartzite pieces. a ATS-001 to $\times 250$ magnification shows orange/red irregular iron oxides. b HA-5814 at $\times 50$ magnification shows black and irregular manganese oxides. c HA-5654 at $\times 250$ magnification shows two black, plain and subrounded undetermined heavy minerals. d HA- 5715 at $\times 250$ magnification shows very small, black, plain and angular pyrites. There are also iron oxides near the pyrites. e ATS-002 at $\times 50$ shows some small, white and bright exfoliating feldspars. f ATS-308 at $\times 250$ magnification shows some small, white and bright mica with changeable structures
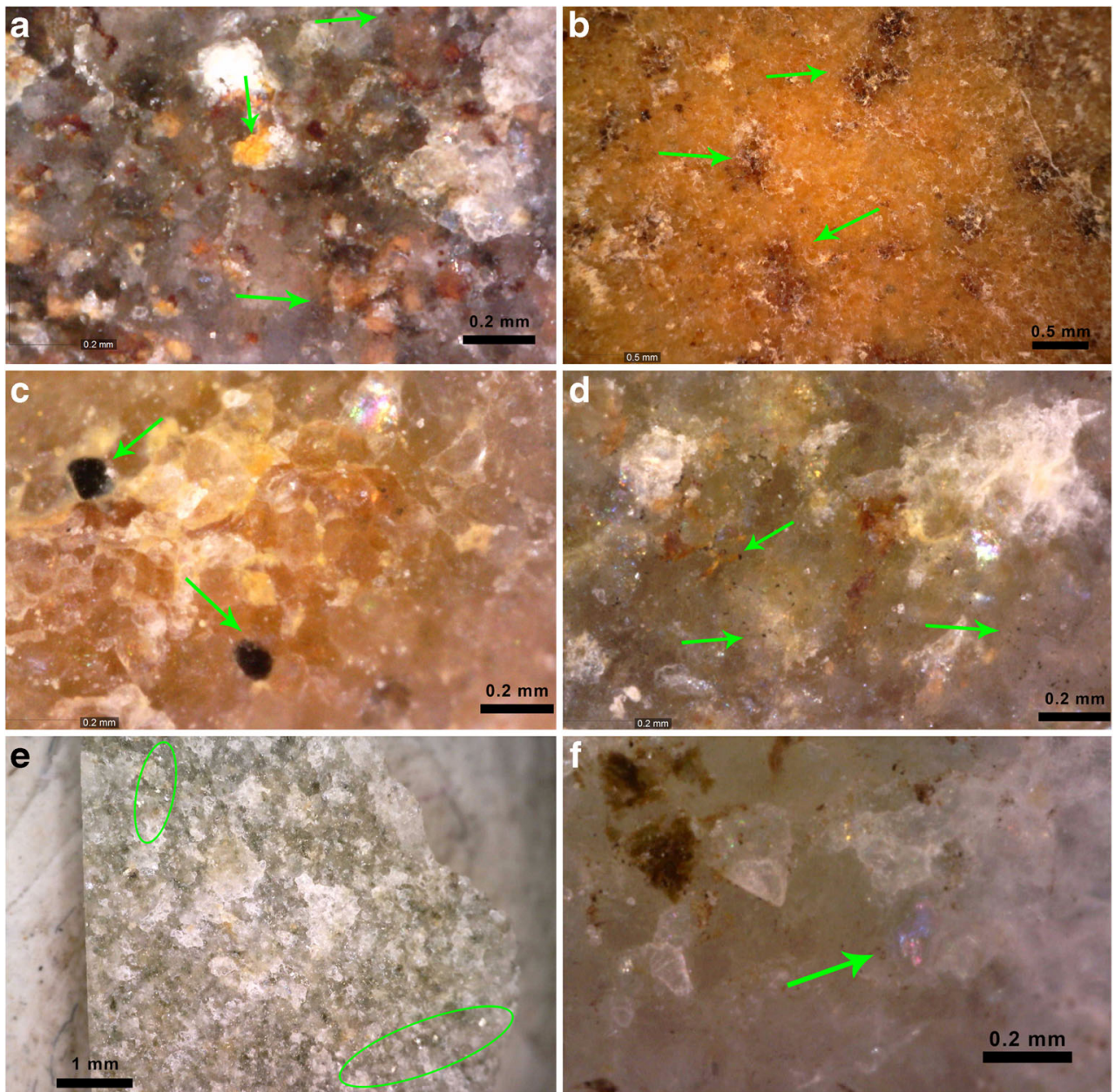

for the assessment of the implement surface. The description of all these features during the data acquisition process, the comparison with the original rough samples subjected to thin section analysis and the comparison with the reference collection of microphotographs helped us to assign petrogenetic groups and types to every artefact. Figure 12 schematically relates both approaches.

MA type (clastic fabric with matrix or non-quartz cement quartz arenite) is characterised through thin section by the association of clastic and cemented texture and floating or punctual packing, as well as by the presence of clastic quartz grains. This is reflected in hand specimen (non-destructive) characterisation through the association between saccharoidal texture and floating or punctual packing. Moreover, by the presence of either flat or irregular outlines on angular or rounded quartz grains because of matrix or cement. There is no presence of lustre or of micro-cracks. Some quartzites show bedding planes on their surfaces. In general, in this type, it is easy to recognise at least 25 different grains, although sometimes this task is complicated by the high presence of matrix or non-quartz cement (Fig. 13).
CA type (clastic quartz arenite) is characterised through thin section by the association of clastic grained texture, tangent or tangent-to-complete packing, and the presence of clastic grains delimited by concave-convex quartz limits. This is reflected through non-destructive techniques in the association of granular texture, tangent or sometimes complete packing, and flat and rounded or angular quartz grain limits. Lustre is present, but it is of low intensity. There is a small increase in the presence of micro-cracks. Bedding appears in some of the studied samples and it is generally easy to recognise $>25$ quartz grains in a $1.6 \times 1.3-\mathrm{mm}$ surface sector (Fig. 13).

OO type (syntaxially overgrown orthoquartzite) is characterised through thin section by the association of clastic grained texture, complete packing, the presence of evenly distributed quartz with undulatory extinction, concavo-convex quartz limits and chiefly by syntaxial quartz overgrowths over the former quartz grains. This is reflected on the quartzite surface by the association between compact and grainy texture, complete packing and flat and rounded quartz grain limits, surrounded by the halo of quartz overgrowth. Most of the samples have medium lustre, while others are more 
Fig. 12 Schematic representation of the features that define the groups and types of quartzites, showing the relationship between the petrographic and nondestructive petrological characterisation. In red, textural and packing and characterisation. In blue, the features of quartz grain and morphology. In black, other diagnostic features. The solid lines that link different columns represent the association of similar characteristics. The dashed lines represent unclear or infrequent relationships. Blue triangles represent relationships where the presence of a quartz grain feature conditions texture or packing. In order to avoid duplicated information, features of quartz grains present in previous phases do not appear in the following types. P: packing; T: texture; F: quartz grain feature; M: morphology of quartz grains. In lustre and micro-cracks (M. crack), 0 means absence, 1 low, 2 medium and 3 high lustre intensity or density of microcracks/scale

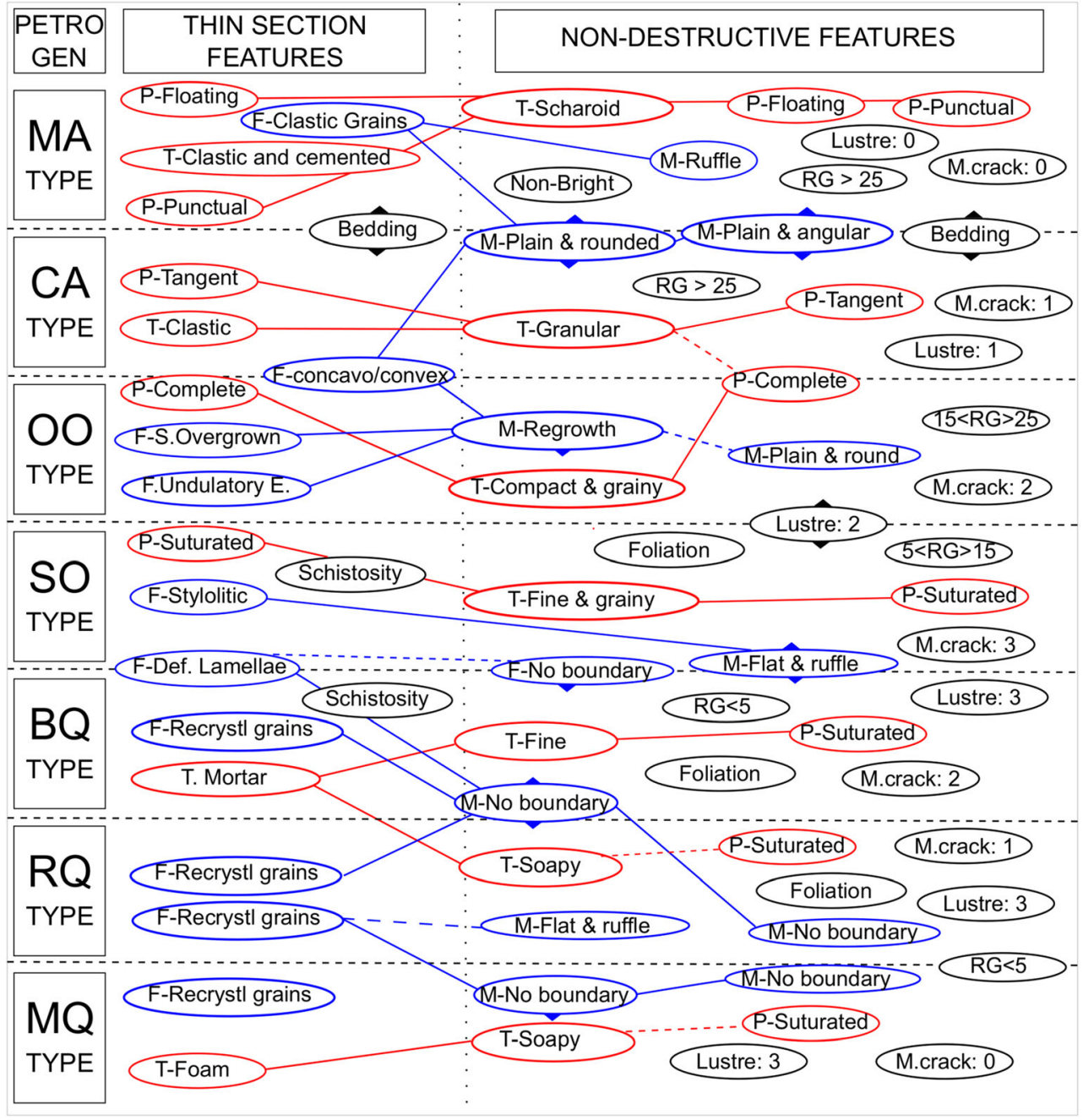

variable. The presence of micro-cracks is also variable. It is easy to recognise grains, although not as easy as in the previous sedimentary quartz arenites (Fig. 14).

SO type (sutured grain orthoquartzite) is characterised through thin section by the association of clastic grained texture, suturated grained packing, stylolitic boundaries, high presence of undulatory extinction and occasional presence of recrystallised grains or deformation lamellae. In hand specimens, there is no boundary detection, but somehow it is related to fine and grainy texture, suturated packing and flat and ruffled grain boundaries. As in the previous type, a variable lustre is common, as well as the presence of surface microcracks. Grains are less easily recognisable than those in the previous type. Foliation structures are easy to recognise on some of the samples (Fig. 14).

BQ type (bulging recrystallised quartzite) is characterised through thin section by the association of mortar texture, suturated packing and presence of stylolitic quartz grains, deformation lamellae, clear undulatory extinction and significant presence of recrystallised grains. It is associated with characteristics on the quartzite surfaces, such as fine texture, suturated packing, flat and ruffled limits of quartz grains and the non-detection of quartz grains. The quantity of recognisable grains is smaller than five and the presence of surface micro-cracks is again variable. The intensity of lustre is high. Finally, and as in the previous type, foliation is obvious in most of the samples (Fig. 15).

RQ type (subgrain rotation recrystallised quartzite) is characterised through thin section by the high presence of recrystallised quartz grains together with mortar texture, suturated packing and presence of stylolitic quartz grains. On the quartzite surface, this type is associated with a soapy texture and absence of evident quartz grain boundaries and few suturated borders. The intensity of lustre is high. As in previous types, foliation is obvious on some samples. There are almost no micro-cracks on the surface (Fig. 15).

MQ type (grain boundary migration recrystallised quartzite) is characterised through thin section by the association of clastic/foam texture, suturated packing, concavo-convex quartz grain limits, presence of deformation lamellae and 

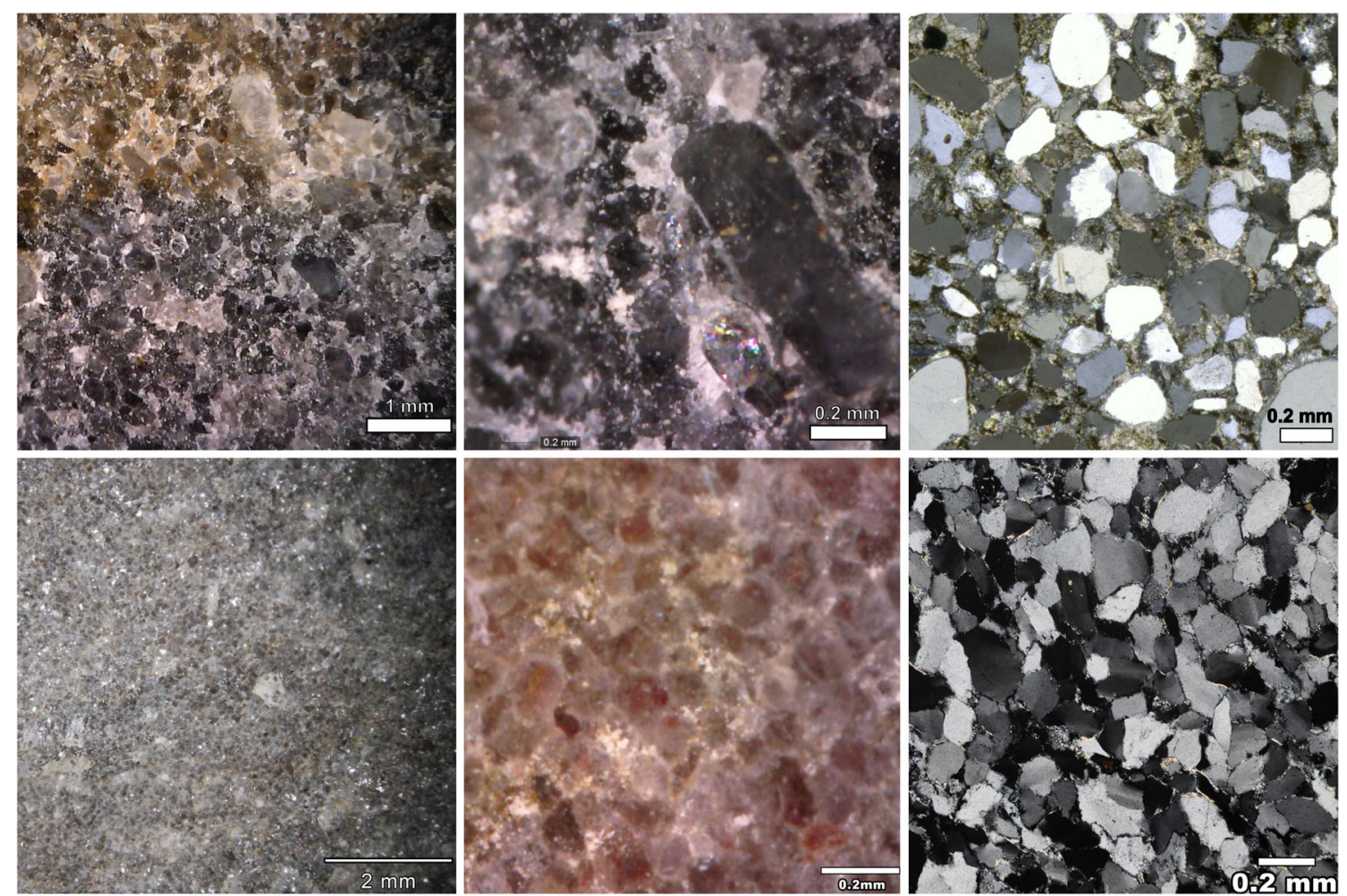

Fig. 13 Pictures at different magnifications of quartz arenites. From top to bottom, samples BR_01 (Beach river 01), an example of an MA type stereomicroscopic images at $\times 50 / \times 20$ and $\times 250$. The images on the right are thin sections under crossed polarisers
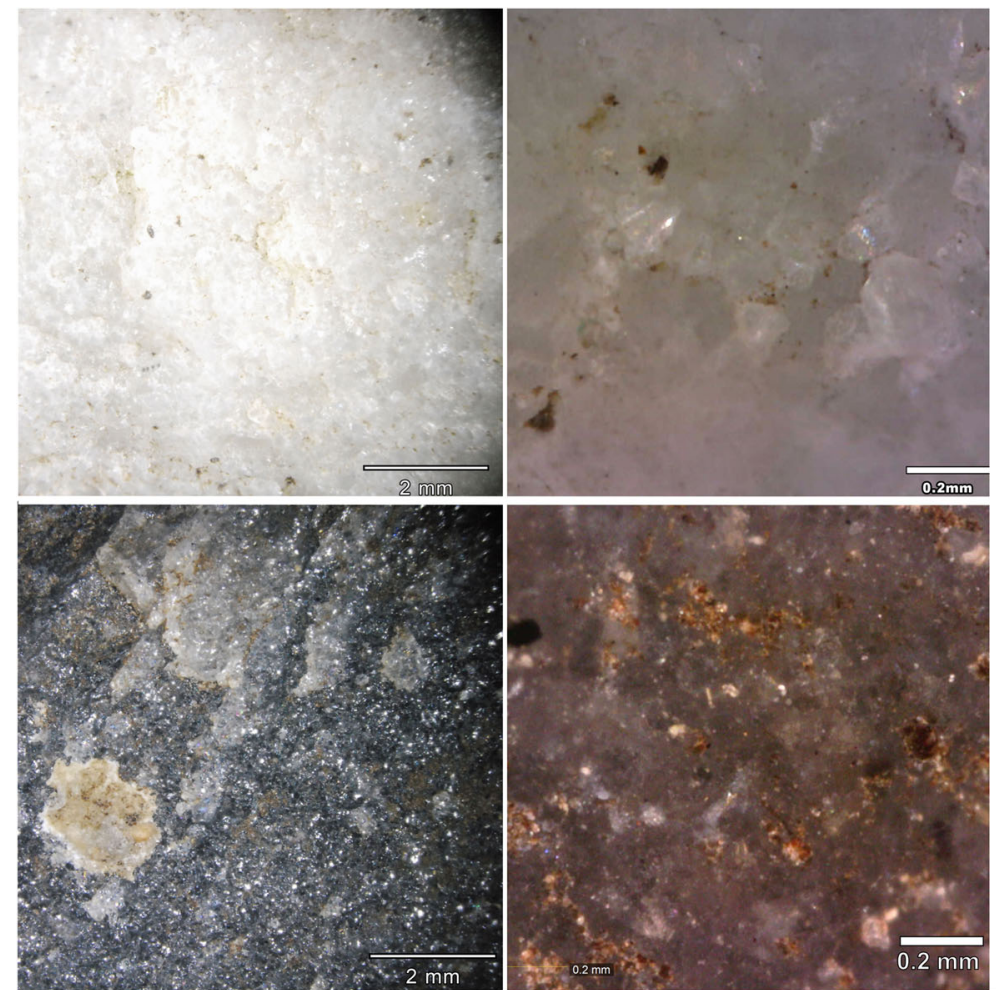
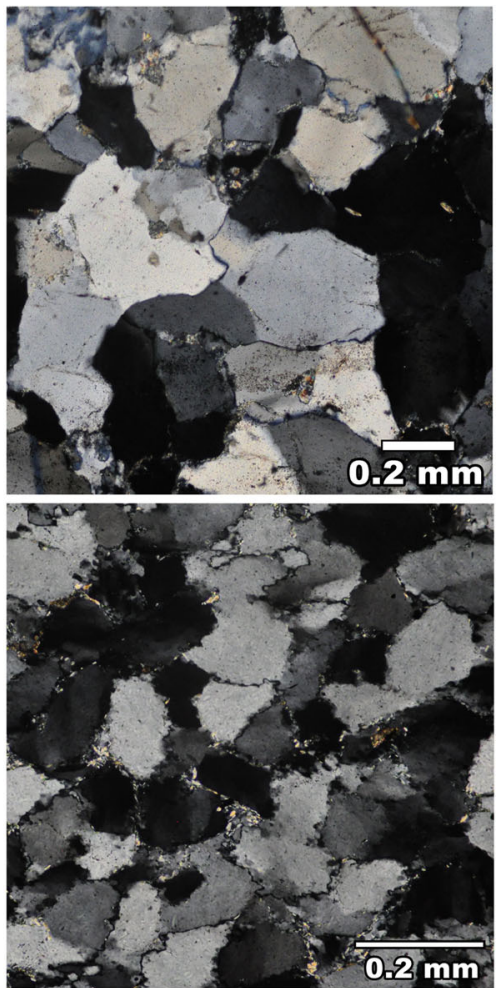

Fig. 14 Pictures at different magnifications of orthoquartzites. From top to bottom, samples ATS-023, an example of an OO type and ATS-302, a SO type. From left to right, the first two pictures are stereomicroscopic images at $\times 20$ and $\times 250$. The images on the right are thin sections under crossed polarised light 

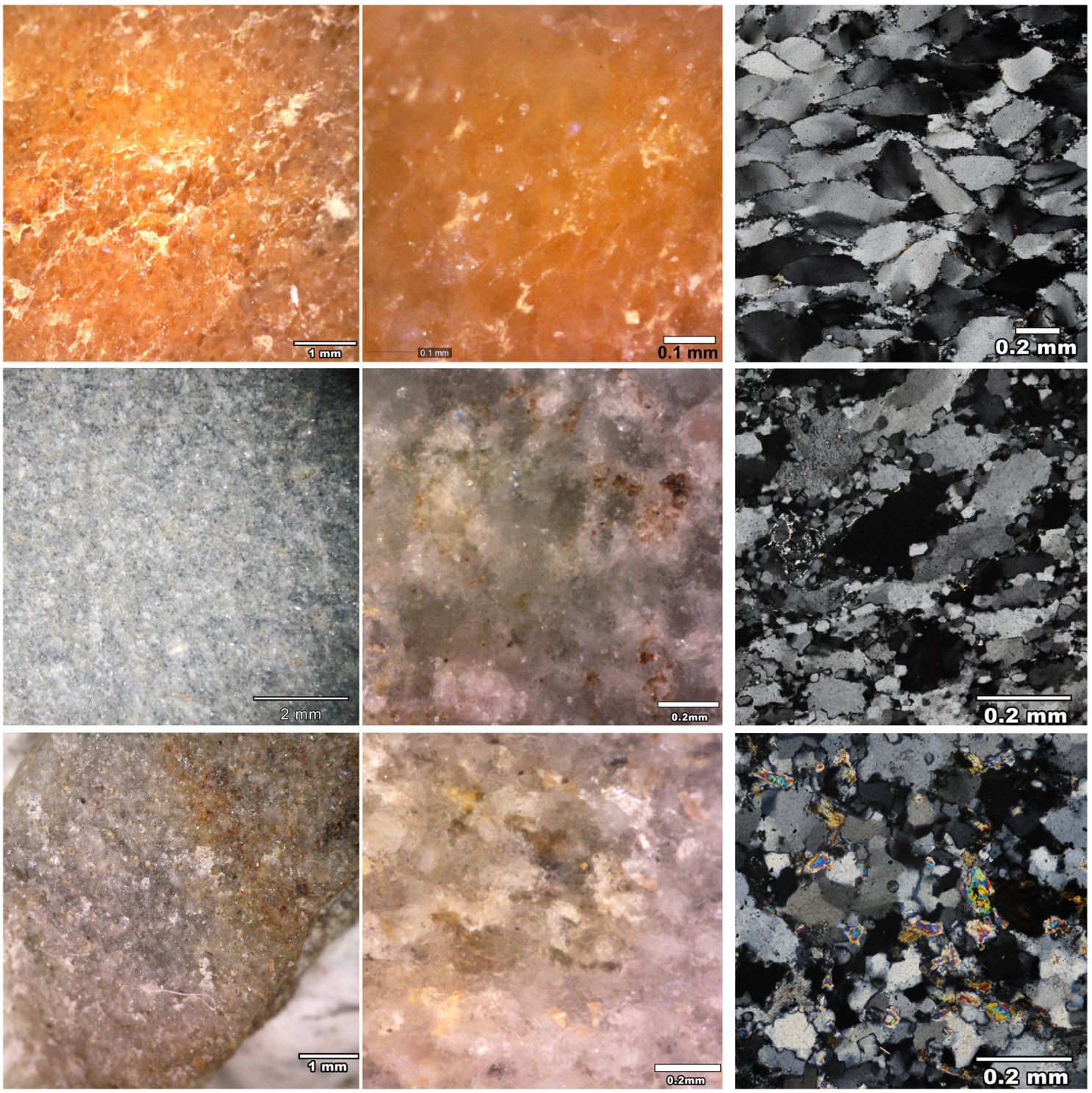

Fig. 15 Pictures at different magnifications of pure quartzites. From top to bottom, samples HA-5847, an example of an BQ type; ATS-195, an

left to right, the first two pictures are stereomicroscopic images at $\times 50 / \times$ $10 / \times 50$ and $\times 250$. The images on the right are thin sections under crossed polarised light

stylolitic quartz grain limits. On the quartzite surface, it is related with soapy texture and the absence of quartz grain boundaries. Intensity of lustre is high, and there is an almost complete absence of micro-cracks on the surface. Foliation is not present (Fig. 15).

Due to methodological limitations, grain size as observed with stereomicroscopy does not show any correlation with sizes measured in thin sections so we could only approximate a general increase in size for the type OO. Therefore, grain size determination is only used as a cumulative feature to describe variability within the types, as a possible consequence of the internal characteristics of the former sediment from which the quartzite was created.

As discussed by Prieto et al. (2019) for the samples studied in thin sections, neither non-quartz mineralogy nor geochemical XRF data show any clear relationship with petrogenetic types. The influence of the mineralogy of the former sediment and post-depositional weathering could explain the variability of non-quartz minerals. It is important to highlight the limited accuracy of mineral detection just by observing the quartzite surface and also the higher influence of postdepositional weathering on the surface than in inner parts.

\section{Management of quartzite in El Habario}

The seven proposed petrogenetic types could be identified by stereomicroscopy in the quarzitic implements $(n=467)$ from El Habario. Metamorphic quartzite is the best represented group owing to the high quantity of the BQ petrogenetic type, with $>50 \%$ of the assemblage. Sedimentary orthoquartzite is 
the second-best represented group, and both petrogenetic types (OO and SO types) are similarly represented. Finally, the group of quartz arenite is underrepresented (Table 2). The most frequent grain size category is heterogeneous distribution, in $47 \%$ of the pieces, even though homogeneous distribution is also well represented, in $37 \%$ of them. Regarding quartzite types and size varieties, nine preferential varieties are associated with $\mathrm{OO}, \mathrm{SO}$ and $\mathrm{BQ}$ types and fine and medium grain sizes.

The most frequent technological category is knapping product, followed by core, and chunk. Cores are restricted to orthoquartzite and quartzite groups (Table 3). Cores made on orthoquartzite and BQ type appear in similar percentages. There is a higher representation of knapping products in the $\mathrm{OO}, \mathrm{SO}$ and BQ types than in RQ and MQ quartzites. Finally, chunks are only represented in MA, OO, SO and BQ types.

We identified 71 cores. The most frequent is the irregular one, followed by discoid, core on flake, levallois and prismatic-shaped core (Online Resource 1). There is no clear correlation between type of core and petrogenetic quartzite type, even though most levallois cores are made on SO type. In addition, the representation of core on flake is different between petrogenetic types, especially comparing the orthoquartzite and quartzite groups.

We identified 355 knapping products. The most frequent type is blank. Core preparation/rejuvenations products are scarce, forming less than $2 \%$ of the assemblage and they are only made on SO, BQ and MQ petrogenetic types. Regarding blanks, there are some differences between petrogenetic types and the quantity of negative scars on them, especially in the comparison between CA and MQ types with all other types. In the first two types, all blanks possess at least two negative scars, while on the other types, each category is represented. There are more blanks with high quantity of negative scars on $\mathrm{SO}$ and RQ types than on BQ and OO types. The latter type is the quartzite with greatest frequency of blanks without negative scars (Online Resource 2). The extension of cortex on dorsal surfaces is different on each petrogenetic type, especially because of the absence of cortical surfaces on MQ blanks and the larger extension of them on CA blanks. In addition, blanks with broad cortex of more than $66 \%$ are more frequent in the OO type than in SO, BQ and RQ (Online Resource 3).

According to the presence of retouch on different petrogenetic types, the CA and RQ types are, on proportion, more retouched than OO, SO, BQ and MQ types (Online Resource 4). In addition, there is a moderate increase in the frequency of retouched artefacts with the increase in deformation/ metamorphic processes throughout the $\mathrm{OO}, \mathrm{SO}$ and $\mathrm{BQ}$ types.

There are clear differences in weight based on the technological categories and petrogenetic types (Fig. 16). They are clear in core category because of the absence of $\mathrm{OO}$ and SO lighter than $40 \mathrm{~g}$. This is especially significant when these cores are compared with those in RQ quartzite, all lighter than that weight. In addition, cores heavier than $600 \mathrm{~g}$ are limited to those made on $\mathrm{OO}$ and BQ petrogenetic types. Moreover, the mean weight indicates that heavier cores are made on $\mathrm{OO}$ and SO types, followed by BQ. Finally, RQ cores are the lightest. There are also differences in weight of knapping product. In general, there is a clear decrease in weight from CA quartz arenite to RQ quartzite.

Table 2 Frequency table of petrological features identified in El Habario based on binocular characterisation.

\begin{tabular}{|c|c|c|c|c|c|c|c|c|c|c|c|c|c|c|c|c|c|c|c|c|}
\hline & & & \multicolumn{18}{|c|}{ Petrogenetic type } \\
\hline & & & \multicolumn{2}{|c|}{ MA } & \multicolumn{2}{|c|}{$\mathrm{CA}$} & \multicolumn{2}{|l|}{$\mathrm{OO}$} & \multicolumn{2}{|c|}{ SO } & \multicolumn{2}{|l|}{ BQ } & \multicolumn{2}{|c|}{ RQ } & \multicolumn{2}{|l|}{ MQ } & \multicolumn{2}{|c|}{ Unknown } & \multicolumn{2}{|l|}{ Total } \\
\hline & & & & $\%$ & & $\%$ & & $\%$ & & $\%$ & & $\%$ & & $\%$ & & $\%$ & & $\%$ & & $\%$ \\
\hline \multirow{11}{*}{$\begin{array}{l}\text { Grain size } \\
\text { characterization }\end{array}$} & \multirow{3}{*}{$\begin{array}{l}\text { Homogeneous and } \\
\text { one mode } \\
\text { distribution }\end{array}$} & Fine grain & & & & & 12 & 11 & 19 & 24 & 67 & 28 & 4 & 21 & 12 & 25 & & & 103 & 22 \\
\hline & & Medium grain & & & & & 19 & 17 & 3 & 4 & 43 & 18 & 4 & 21 & & & & & 69 & 15 \\
\hline & & Coarse grain & & & & & & & & & & & & & & & & & & \\
\hline & \multirow{3}{*}{$\begin{array}{l}\text { Heterogeneous and } \\
\text { two modes } \\
\text { distribution }\end{array}$} & Fine grain & & & & & 11 & 10 & 7 & 9 & 12 & 5 & & & & & & & 30 & 6 \\
\hline & & Medium grain & & & 1 & 25 & 11 & 10 & 4 & 5 & 13 & 5 & 2 & 11 & & & & & 31 & 7 \\
\hline & & Coarse grain & & & & & 1 & 1 & & & 1 & & & & & & & & 2 & 0 \\
\hline & \multirow{3}{*}{$\begin{array}{l}\text { Heterogeneous } \\
\text { distribution }\end{array}$} & Fine grain & & & & & 25 & 23 & 30 & 38 & 41 & 17 & 5 & 26 & 37 & 753 & 3 & 30 & 107 & 23 \\
\hline & & Medium grain & 1 & 100 & 2 & 50 & 30 & 27 & 15 & 19 & 60 & 25 & 4 & 21 & & & & & 112 & 24 \\
\hline & & Coarse grain & & & 1 & 25 & 2 & 2 & 2 & 3 & 1 & 0 & & & & & & & 6 & 1 \\
\hline & \multirow[t]{2}{*}{ Unknown } & & & & & & & & & & & & & & & & 7 & 70 & 7 & 1 \\
\hline & & Total & 1 & 0 & 4 & 1 & 111 & 24 & 80 & 17 & 238 & 51 & 19 & 4 & 41 & 1 & 10 & 2 & 467 & 100 \\
\hline
\end{tabular}

Columns are petrogenetic types and rows contain the characteristics of grains according to size, classified first by distribution and second by size itself. Values in italics are the categories representing more than $10 \%$ of the total cases. Values in bold are the categories representing between 5 and $10 \%$ of cases. Finally, values in bold italics are the categories representing between 1 and $5 \%$ of cases 
Table 3 Frequency table of main technological categories identified in El Arteu grouped by petrogenetic types of quartzite

\begin{tabular}{|c|c|c|c|c|c|c|c|c|c|c|c|}
\hline & \multicolumn{11}{|c|}{ Technological order } \\
\hline & \multicolumn{3}{|c|}{ Cores } & \multicolumn{3}{|c|}{ Knapping prdct. } & \multicolumn{3}{|c|}{ Chunk } & \multicolumn{2}{|l|}{ Total } \\
\hline & $\sum$ & $\%$ & rel.\% & $\sum$ & $\%$ & rel.\% & $\sum$ & $\%$ & rel.\% & $\sum$ & $\%$ \\
\hline MA & & & & & & & 1 & 2 & 100 & 1 & 0 \\
\hline $\mathrm{CA}$ & & & & 4 & 1 & 100 & & & & 4 & 1 \\
\hline $\mathrm{OO}$ & 14 & 20 & 13 & 90 & 25 & 81 & 7 & 17 & 6 & 111 & 24 \\
\hline $\mathrm{SO}$ & 9 & 13 & 11 & 63 & 18 & 79 & 8 & 20 & 10 & 80 & 17 \\
\hline BQ & 40 & 56 & 17 & 180 & 51 & 76 & 18 & 44 & 8 & 238 & 51 \\
\hline RQ & 6 & 8 & 32 & 13 & 4 & 68 & & & & 19 & 4 \\
\hline MQ & 1 & 1 & 25 & 3 & 1 & 75 & & & & 4 & 1 \\
\hline Undetermined & 1 & 1 & 10 & 2 & 1 & 20 & 7 & 17 & 70 & 10 & 2 \\
\hline Total & 71 & 15 & & 355 & 76 & & 41 & 9 & & 467 & 100 \\
\hline
\end{tabular}

Columns are the categories of knapping products and the total of items belonging to each petrogenetic type. The columns $\%$ are the percentage of each petrogenetic type in relation to each category of knapping product, while the columns rel. $\%$ are the percentage of each category of knapping product in relation to each petrogenetic type of quartzite. Values in italics are the categories representing more than $10 \%$ of the total cases. Values in bold are the categories representing between 5 and $10 \%$ of cases. Finally, values in bold italics are the categories representing between 1 and $5 \%$ of cases
In addition, the weight of orthoquartzites and BQ type is more variable than RQ and MQ types. Finally, chunk weight also differs between the OO, SO and BQ petrogenetic types due to the decrease in mean weight and variability as deformation increases.

\section{Management of quartzite in El Arteu}

Six petrogenetic types have been identified in the quarzitic implements $(n=237)$ from El Arteu. Sedimentary orthoquartzite $(47 \%)$ is the best represented group and quartz arenite (21\%) is

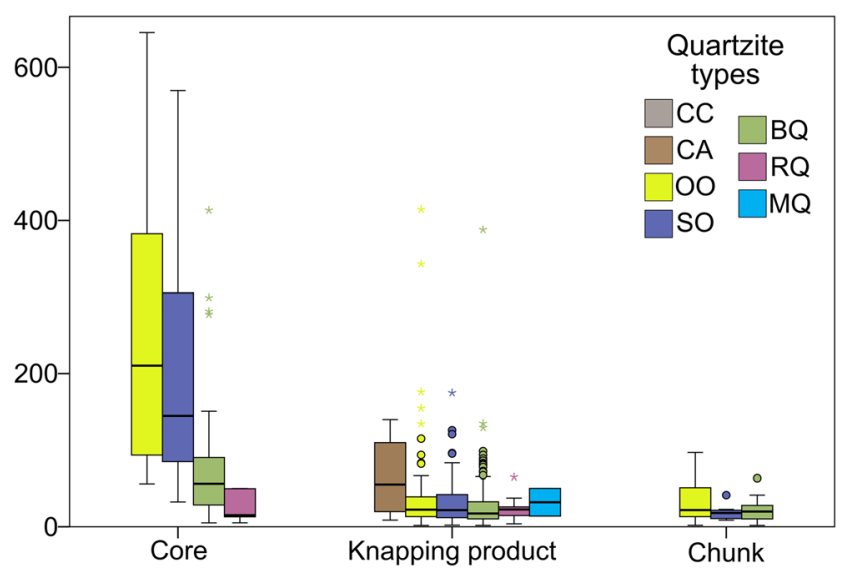

Fig. 16 Boxplot showing the distribution of weight (grams) of all lithic remains grouped first by technological order and second by petrogenetic type. There are another five quartzites heavier than $650 \mathrm{~g}$ not shown in the chart: one core and one knapping product on $\mathrm{OO}$ orthoquartzite weighing 1124.7 and $952.8 \mathrm{~g}$ and another three BQ quartzites cores with weights of $804.45,722.62$ and $689.34 \mathrm{~g}$ the second most important one. Finally, the group of metamorphic quartzite is the least frequent (19\%) (Table 4). The most frequent grain size distribution category is homogeneous distribution around one mode in $46 \%$ of cases, even though general heterogeneous distribution is also well represented. Regarding grain size, the most frequent categories are fine and medium grain sizes. We identified six preferential varieties: three belong to OO type, one with fine size and homogeneous distribution and another two medium-sized varieties with homogeneous and heterogeneous distribution. Another two varieties are BQ and SO types with fine grain size and homogeneous distribution. The last one is the CA type with heterogeneous distribution and medium quartz grain sizes.

The most frequent technological category is knapping product, followed by chunk and core. Except for the RQ quartzite, cores are represented in every petrogenetic type (Table 5). Finally, chunks are well represented in the MA, RQ and OO types, while they are underrepresented in the $\mathrm{SO}$ and CA petrogenetic types.

We identified 17 cores in the whole collection. The most frequent type is core on flake, with eight, followed by discoid and irregular ones, represented by five and four items, respectively. There is only one prismatic-shaped core. There is no clear correlation between type of core and petrogenetic types of quartzite (Online Resource 5).

One hundred seventy-four knapping products were identified in the lithic assemblage from El Arteu. The most frequent type is blank, amounting to over $97 \%$ of the items. Core preparation/rejuvenation products are scarce and they are only represented on $\mathrm{CA}, \mathrm{OO}$ and $\mathrm{SO}$ types. There is a great variability in the number of negative scars on blanks depending on the quartzite types because of the smaller presence of negative 
Table 4 Frequency table of petrological features identified in El Arteu based on binocular characterisation.

Petrogenetic type

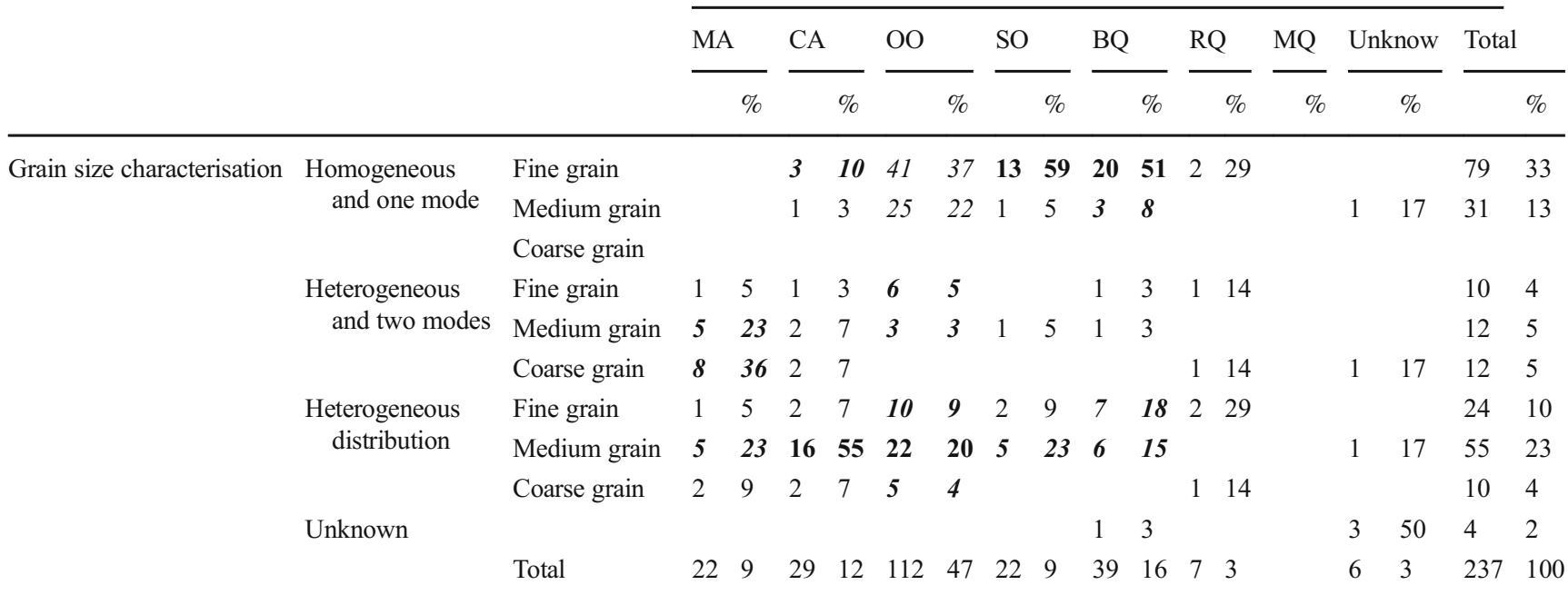

Columns are petrogenetic types and rows contain the characteristics of grains according to size, classified first by distribution and second by size itself. Values in italics are the categories representing more than $10 \%$ of the total cases. Values in bold are the categories representing between 5 and $10 \%$ of cases. Finally, values in bold italics are the categories representing between 1 and 5\% of cases

scars on the quartz arenite group than on orthoquartzites (Online Resource 6). Cortical areas on blanks are more frequent in the CA type, while they are uncommon in the others, especially in SO type (Online Resource 7).

$\mathrm{SO}$ orthoquartzites and the group of quartzite are, in general, more retouched than other types of quartzites. In addition, $\mathrm{OO}$ orthoquartzite is more retouched than the quartz arenite group (Online Resource 8). The OO type, followed by the $\mathrm{SO}$ and the $\mathrm{BQ}$ ones, are the petrogenetic types with the highest representation of blanks with multiple primary types.

The relationship between petrogenetic types and technology through weight demonstrates clear differences (Fig. 17). Cores made on MA type are heavier than cores made on other petrogenetic types. Knapping products and chunks follow similar patterns, and there are none lighter than $5 \mathrm{~g}$ in the MA type.

\section{Discussion}

\section{From a sample to the whole: losing precision to gain information}

Textural and quartz grain features through microscopic nondestructive techniques show an analogous association of
Table 5 Frequency table of the categories of knapping products identified in El Habario grouped by the petrogenetic types of quartzite

\begin{tabular}{|c|c|c|c|c|c|c|c|c|c|c|c|}
\hline & \multicolumn{11}{|c|}{ Technological order } \\
\hline & \multicolumn{3}{|c|}{ Cores } & \multicolumn{3}{|c|}{ Knapping product } & \multicolumn{3}{|c|}{ Chunk } & \multicolumn{2}{|c|}{ Total } \\
\hline & $\sum$ & $\%$ & $\%$ rel & $\sum$ & $\%$ & $\%$ rel & $\sum$ & $\%$ & $\%$ rel & $\sum$ & $\%$ \\
\hline MA & 4 & 24 & 18 & 11 & 6 & 50 & 7 & 15 & 32 & 22 & 9 \\
\hline $\mathrm{CA}$ & 1 & 6 & 3 & 25 & 14 & 86 & 3 & 7 & 10 & 29 & 12 \\
\hline $\mathrm{OO}$ & 6 & 35 & 5 & 80 & 46 & 71 & 26 & 57 & 23 & 112 & 47 \\
\hline $\mathrm{SO}$ & 2 & 12 & 9 & 19 & 11 & 86 & 1 & 2 & 5 & 22 & 9 \\
\hline BQ & 2 & 12 & 5 & 30 & 17 & 77 & 7 & 15 & 18 & 39 & 16 \\
\hline RQ & & & & 5 & 3 & 71 & 2 & 4 & 29 & 7 & 3 \\
\hline Undetermined & 2 & 12 & 33 & 4 & 2 & 67 & & & & 6 & 3 \\
\hline Total & 17 & 7 & & 174 & 73 & & 46 & 19 & & 237 & 100 \\
\hline
\end{tabular}

Columns are the main technological categories and the total of items of each raw material. The columns $\%$ are the percentage of each raw material in relation to each technological category, while the columns $\%$ rel. are the percentage of each technological category in relation to each type. Values in italics are the categories representing more than $10 \%$ of the total cases. Values in bold are the categories representing between 5 and $10 \%$ of cases. Finally, values in bold italics are the categories representing between 1 and $5 \%$ of cases 


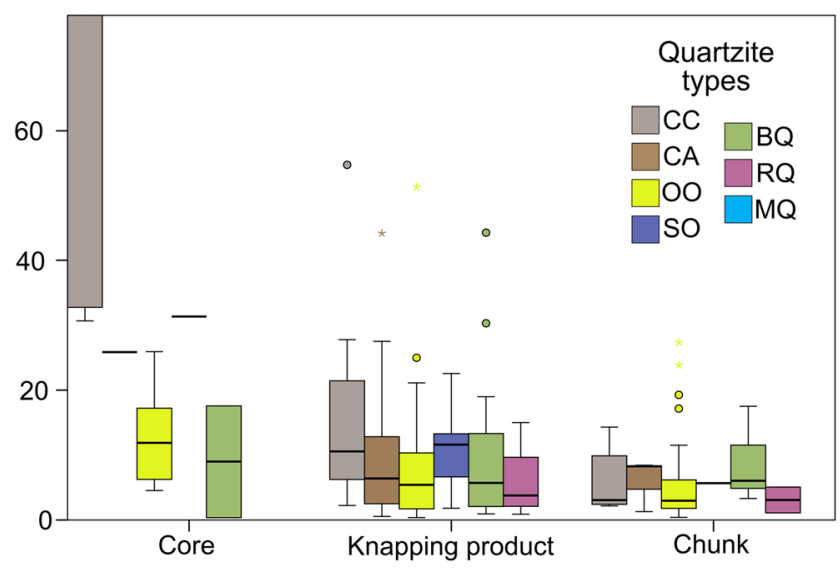

Fig. 17 Boxplot showing the distribution of weight in grams of all lithic remains grouped first by technological order and second by raw material in the chart on the left, and by petrogenetic type in the chart on the right. There are another four MA petrogenetic quartzite type heavier than $60 \mathrm{~g}$, not shown in the chart (a 722-g chunk, a 296-g blank and two cores 192 and $263 \mathrm{~g}$ in weight)

features and forces to those appreciated through petrographic characterisation. Nevertheless, the diagenetic or metamorphic changes (the forces) that can be more accurately determined by petrographic analysis are not easily appreciated on the present surface of the rock as they are in thin section. However, the correlation between destructive petrography and stereomicroscope characterisation allows us to recognise some geologic processes in the rocks and, therefore, the petrogenetic types. In this way, it lets us extrapolate the information from the petrographic characterisation of a representative sample to the complete collection that we study by nondestructive methods.

In quartz arenites, grains are easy to recognise and the borders from the former clastic sediment are well defined. They are only modified by the presence of matrix or cement. In this group, compaction and cementation are the diagenetic processes that consolidated former sediments into sedimentary rocks. In the group of orthoquartzites, grain borders are not so easy to observe in hand specimens, since they are modified by silica overgrowth (more evident in the OO type) and the deformation of quartz grains. For these reasons, and also because of the increase in undulatory extinction on quartz grains, lustre is more intense. The presence of micro-cracks is more frequent, due to the increase of compactness. In SO type, foliation is also a consequence of the deformation. Overgrowth and deformation are the main forces that affect and create these features on rock surfaces. In the group of metamorphic quartzites, individual grains could not be recognised due to high deformation, but also because of the presence of new small recrystallised grains that create a bright and crystalline surface. The progression of the degree of metamorphism generates more crystalline structures, resulting in very smooth and flat surfaces that make it impossible to recognise the original quartz grains in hand specimens and sometimes also in thin sections.

Despite the limitation imposed by grain size observation on quartzite surfaces, we could accomplish grain size measurement of each lithic piece using qualitative categories based on descriptive criteria for medium size and quartz grain distribution. These criteria are based on petrographic characterisation of samples using a large quantity of high-resolution measurements (Prieto et al. 2019). These categories allow us to understand preferential varieties selected by prehistoric societies.

Finally, mineral characterisation was not correlated with the information provided by other criteria. As discussed above, the influence of the mineralogy of the former sediment and especially post-depositional weathering could explain the variability of non-quartz minerals.

The proposed methodology helped us to understand not only a few samples of the quartzites, but the complete assemblage of these two Middle-Palaeolithic sites, and therefore, we were able to propose human activities carried out in both places.

\section{From geoarchaeological characterisation to human knowledge}

In El Habario site, the best represented quartzite type is BQ, followed by $\mathrm{OO}$ and SO types. Except for the OO type, without core preparation/rejuvenation products, all technological products are represented, indicating complete chaines opératoires in all three types. The degree of exploitation of SO type and the quartzite group seems to be greater than of OO type (Fig. 18). The representation of quartz arenites is residual, showing only partial processes. MQ and RQ types are also slightly represented with a partial process of lithic reduction. Nevertheless, these chaines opératoires are more complex, and they are more related with the last stages of the shaping processes.

This information points to different management strategies depending on each quartzite type and related with the properties of each one. We observe fragmented chaînes opératoires reflecting the creation of storage and toolkits on determined quartzite types, associated with the conglomerate outcrops near El Habario site, which contain rock pebbles of the petrogenetic types MA, OO, SO and BQ. BQ and SO type could be the main product of exploitation, while OO type could be a secondary product. We also observed the discarding of previously stocked raw material and partial reparation and partial discard of toolkits made on materials unrepresented in the adjacent quartzite conglomerate (RQ and MQ types).

In $\mathrm{El} \mathrm{Arteu,} \mathrm{there} \mathrm{is} \mathrm{a} \mathrm{higher} \mathrm{presence} \mathrm{of} \mathrm{quartz} \mathrm{arenites} \mathrm{and}$ OO type and a decrease in BQ and SO types. Complete chaînes opératoires on quartz arenites are clear although they are weakly exploited. The high representation of OO type and the presence of all technological products show that this quartzite was knapped in the site as the main raw material. 


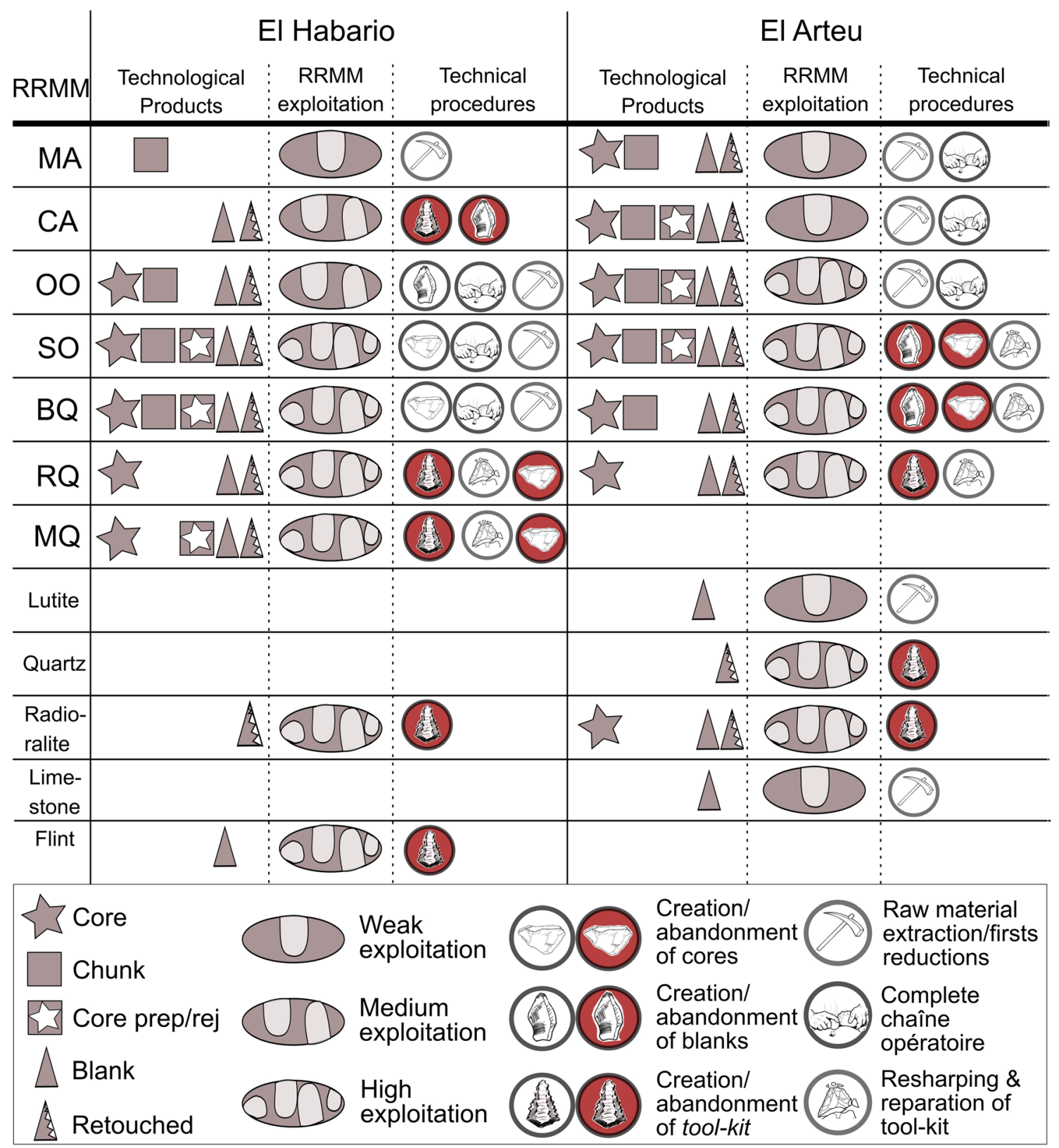

Fig. 18 Systematic management strategies followed by human populations who inhabited El Habario and El Arteu, grouped by raw material and petrogenetic types. For abbreviations: MA for clastic fabric with matrix or non-quartz cement quartz arenite, CA for clastic quartz- arenite, $\mathrm{OO}$ for syntaxially overgrown orthoquartzite, $\mathrm{SO}$ for sutured grain orthoquartzite, BQ for bulging recrystallised quartzite, RQ for subgrain rotation recrystallised quartzite and $\mathrm{MQ}$ for grain boundary migration recrystallised quartzite
Its degree of exploitation shows that it was used intensively, similar to SO and BQ types, although they are less represented. RQ type seems to be also intensively exploited, although not every technological product is represented (Fig. 18).

This information points to different management strategies than at the previous site, probably due to the availability of different quartzite types. We observe fragmented chaînes opératoires which reflects the use of storage and toolkits, like those created in El Habario, certifying the fragmented character of Middle Palaeolithic stone tool technology (Meignen et al. 2009; Turq et al. 2013, 2017). We also observed the use of CA quartz arenites and the OO type, probably obtained in the fluvial deposits near El Arteu. Their use is probably related to a versatility phenomenon rather than an expedient one (Vaquero and Romagnoli 2017).

These data underline the complex management of raw material made by Middle-Palaeolithic societies to exploit their habitat in the Cantabrian Region, as it was also suggested by other studies (Carrión et al., 2008, 2013; Gonzalez-Urquijo et al. 2005). Once we could individualise each type of 
quartzite, we observed different managements guided by their features for knapping, their availability and probably by human decisions on changeable circumstances. The coexistence of multiple methods of lithic reduction in the same layer could be the consequence of these issues, as it was also suggested by other researches along the Cantabrian Region (Carrión and Baena 1999; Baena et al. 2012; Maillo 2007; Rios-Garaizar 2010). The use of different environments where different types of quartzite (or other raw materials) was caught/ selected also contributes to this variability, as it was suggested by other authors (Castanedo 2001; Manzano et al. 2005; RiosGaraizar 2012; Roy et al. 2017). Finally, lithic assemblages also show a complex management as a consequence of the different human decisions for taking advantage in the changeable environment where societies inhabited (Carrión et al. 2013; Cuartero et al. 2015; Santamaría et al. 2010). We would like to underline that these human and socio-economic standpoints based on complex management of lithic resources in Middle-Palaeolithic contexts are being proposed not only in the Cantabrian Region, but also in other parts of Europe (Richter 2016; Turq et al. 2013, 2017). All these data are transforming our chrono-cultural perspectives of lithic variability into a more complex human, social and economic perspectives.

\section{Conclusions}

Our main goal in this paper was to explore and fill the gap between petrographic and non-destructive characterisation of quartzite. The starting point of this research is the characterisation of 18 samples through thin-section analysis (Prieto et al. 2019). This characterisation was based on qualitative (also quantitative) description of texture, packing and quartz grain features; the quantitative characterisation of size, morphology and orientation of quartz grains; and the determination of nonquartz minerals. This information helped us to understand the variability of the term quartzite but also to adopt seven petrogenetic types that cover the wide spectrum of rocks used under this term, from the pure sedimentary arenites, the more deformed quartz arenite and the truly metamorphic quartzite types, all of them exploited as raw materials in Prehistory. This information is used to understand different features on the quartzite surface, such as texture, packing, quartz grain morphologies, lustre, presence of micro-cracks, bedding and foliation, and also, the grain size and the non-quartz minerals on the rock surfaces. All these characteristics have been precisely described and they have been associated with the information derived by petrographic analysis. This procedure helps us to classify the different types of quartzite, not only for a sample of the assemblage but for the whole collection. In addition, we also establish different grain size varieties. Despite the lower resolution of the non-destructive approach, we have filled the gap between petrographic and nondestructive characterisation using a solid geoarchaeological procedure. An increase in the number of quartzites analysed, the application of data mining and machine learning software on micro-pictures or even better recognition of weathering effects could improve the presented methodology (BustosPérez et al. 2019).

This study also contributes to the knowledge of raw material management strategies during the Middle Palaeolithic in the Cantabrian Region. Management strategies are related with the creation of stores of blanks or cores of a determined type, their discard in a situation of abundance of raw material, their exploitation depending on the quartzite qualities or toolkit production and maintenance of determined types. All these behaviours are inserted in a fragmented management strategy taking into account the geographic and temporal variables. These data point at the variability and especially the versatility of management of quartzites by Middle Palaeolithic people in a complex economy and society (Carrión et al. 2013; Turq et al. 2013). The data suggest hidden strategies that could only be analysed by the geoarchaeological characterisation of quartzites. The application of the criteria to characterize the materials in potential source areas would enable the determination of the mechanisms used for the selection of raw materials and/or the short- and long-distance mobility circuits and territories of the societies that inhabited this area.

Acknowledgements The authors thank Professor Javier Baena and MUPAC (Archaeological and Prehistorical Museum of Cantabria) for permission to study and sample the lithic archaeological material. The Department of Mineralogy and Petrology of UPV/EHU for access to the laboratories, thin-section preparation and X-ray fluoresce. The authors would like to thanks the two anonymous reviwers for their constructive comments which greatly improve this manuscript. A. Prieto is a collaborator in the project HAR2016-76760-C3-2-P funded by the Spanish Ministry of Science and FEDER funds.

Funding information Open Access funding provided by Projekt DEAL. This research was partially supported by the project HAR2017-82483C3-1-P financed by the Spanish Ministry of Science and the Consolidated Research Group in Prehistory of the Basque Country University (IT1223-19). A. Prieto is funded by the Education Department of the Government of the Basque Country through a postdoctoral fellowship (POS_2018_1_0021).

Open Access This article is licensed under a Creative Commons Attribution 4.0 International License, which permits use, sharing, adaptation, distribution and reproduction in any medium or format, as long as you give appropriate credit to the original author(s) and the source, provide a link to the Creative Commons licence, and indicate if changes were made. The images or other third party material in this article are included in the article's Creative Commons licence, unless indicated otherwise in a credit line to the material. If material is not included in the article's Creative Commons licence and your intended use is not permitted by statutory regulation or exceeds the permitted use, you will 
need to obtain permission directly from the copyright holder. To view a copy of this licence, visit http://creativecommons.org/licenses/by/4.0/.

\section{References}

Álvarez-Alonso D, De Andrés M, Rojo J (2013) La captación de materias primas líticas durante el Paleolítico en el oriente de Asturias, y su caracterización litológica en la cuenca de los ríos Sella y Cares (Asturias, España). VIII Reunión de Cuaternario Ibérico, La Rinconada-Sevilla, 1:296-299

Andrefsky W (1994) Raw-material availability and the Organization of Technology. Am Antiq 59(1):21-34

Baena J, Carrión E, Ruiz B, Ellwood B, Sesé C, Yravedra J et al (2005) Paleoecología y comportamiento humano durante el Pleistoceno Superior en la comarca de Liébana: La secuencia de la Cueva de El Esquilleu (Occidente de Cantabria, España). In: Montes R, Lasheras JA (eds) Actas de la reunión científica: Neandertales cantábricos, estado de la cuestión. Celebrada en el Museo de Altamira los días 20-22 de Octubre de 2004. Ministerio de Cultura, Madrid, pp 461-487

Baena J, Carrión E, Cuartero F, Fluck H (2012) A chronicle of crisis: the Late Mousterian in North Iberia (Cueva del Esquilleu, Cantabria, Spain). Quat Int 247:199-211. https://doi.org/10.1016/j.quaint. 2011.07.031

Barnolas A, Pujalte V (2004) La cordillera pirenaica: Definición, límites y división. In: Vera JA (ed) Geología de España. SGE-IGME, Madrid, pp 233-241

Bastida F (1982) La esquistosidad primaria y las microestructuras de las cuarcitas en la zona Asturoccidental-leonesa. Trabajos de Geología 12:159-185

Bastida F (2004) Zona Cantábrica. In: Vera JA (ed) Geología de España. SGE-IGME, Madrid, pp 25-49

Binns RA, McBryde I (1969) Preliminary report on a petrological study of ground-edge artefacts from north-eastern New South Wales, Australia. Proc Prehist Soc 35(10):229-235

Blomme A, Degryse P, Van Peer P, Elsen J (2012) The characterization of sedimentary quartzite artefacts from Mesolithic sites, Belgium. Geol Belg 15(3):193-199

Bustos-Pérez G, Díaz S, Baena J (2019) An experimental approach to degrees of rounding among lithic artifacts. J Archaeol Method Theory 26:1243-1275. https://doi.org/10.1007/s10816-018-9409-8

Carrión E (2002) Variabilidad técnica en el Musteriense de Cantabria. Dissertation, Universidad Autónoma de Madrid

Carrión E, Baena J (1999) El Habario, un yacimiento musteriense al aire libre en los Picos de Europa cántabros. Espacio, Tiempo y Forma, Serie I, Prehistoria y Arqueología, 12:81-101

Carrión E, Baena J (2005) El Habario: una ocupación musteriense al aire libre en los Picos de Europa. In: Montes R, Lasheras JA (eds) Actas de la reunión científica: Neandertales cantábricos, estado de la cuestión. Celebrada en el Museo de Altamira los días 20-22 de Octubre de 2004. Ministerio de Educación y Cultura, Madrid, pp 446-460

Carrión E, Baena J, Conde C, Cuatero F, Roca M (2008) Variabilidad técnica del Paleolítico medio en el sudoeste de Europa. Treballs d'arqueologia 14:279-318

Carrión E, Baena J, Torres Navas C (2013) Una tecnología en extinción. Procesos técnicos y tecnológicos del final del Musteriense en el Norte Peninsular Mainake, 33:251-274

Castanedo I (2001) Adquisición y aprovechamiento de los recursos líticos en la Cueva de la Flecha. Munibe 53:3-18

Cnudde V, Dewanckele J, De Kock T, Boone M, Baele JM, Crombé P et al (2013) Preliminary structural and chemical study of two quartzite varieties from the same geological formation: a first step in the sourcing of quartzites utilized during the Mesolithic in northwest Europe. Geol Belg 16(1-2):27-34

Cuartero F, Alcaraz-Castaño M, López-Recio M, Carrión-Santafé E, Baena-Preysler J (2015) Recycling economy in the Mousterian of the Iberian Peninsula: the case study of El Esquilleu. Quat Int 361: 113-130. https://doi.org/10.1016/j.quaint.2014.11.059

Dalpra CL, Pitblado BL (2016) Discriminating quartzite sources petrographically in the Upper Gunnison Basin, Colorado: Implications for Paleoamerican Lithic-Procurement Studies PaleoAmerica:1-10. https://doi.org/10.1080/20555563.2015.1137684

Demars PY (1980) Les matières premières utilisées au Paléolithique supérieur dans le Bassin de Brive. Dissertation, Université de Bordeaux

Dibble HL, Holdaway SJ, Lin SC, Braun DR, Douglass MJ, Iovita R et al (2017) Major fallacies surrounding stone artifacts and assemblages. J Archaeol Method Theory 24(3):813-851. https://doi.org/10.1007/ s10816-016-9297-8

Dixon JE, Cann JR, Renfrew C (1968) Obsidian and the origins of trade. Sci Am 218:38-46

Earle T, Ericson J (1977) Exchange systems in prehistory. Academic Press, New York

Fernández-Eraso J, García-Rojas M (2013) Tipología Analítica. In: García-Díez M (ed) Métodos y técnicas de análisis y estudio en Arqueología prehistórica. De lo técnico a la reconstrucción de los grupos humanos. Universidad del País Vasco/Euskal Herriko Unibertsitatea, Bilbao, pp 479-497

Floss H (1990) Rohmaterialversorgung im Paläolithikum des Mittelrheingebietes. Dissertation Universität zu Köln. Bonn: Habelt

Folk R (1974) Petrology of sedimentary rocks. Hemphill Publishing Company, Austin

García-Rojas M (2010) Propuesta de descripción y clasificación de los productos de debitado desde la Tipología Analítica. Zéphyrus 66: 93-107

García-Rojas M (2014) Dinámicas de talla y gestión de las materias primas silíceas a finales del Pleistoceno en el País Vasco. Dissertation, Universidad del País Vasco/Euskal Herriko Unibertsitatea

Geneste JM (1985) Analyse lithique d'industries moustériennes du Périgord: une approche technologique du comportemen des grupes humains au Paléolithique moyen. Dissertation, Université de Bordeaux

Gonzalez-Urquijo J, Ibáñez JJ, Rios-Garaizar J, Bourguignon L, Castaños P, Tarriño A (2005) Excavaciones recientes en Axlor. Movilidad y planificación de actividades en grupos de neandertales. In: Montes R, Lasheras JA (eds) Actas de la reunión científica: Neandertales cantábricos, estado de la cuestión. Celebrada en el Museo de Altamira los días 20-22 de Octubre de 2004. Ministerio de Cultura, Madrid, pp 461-487

Howard JL (2005) The quartzite problem revisited. J Geol 113(6):707713. https://doi.org/10.1086/449328

Kowalski BR, Schatzki TF, Stross FH (1972) Classification of archaeolgical artifacts by applying pattern recognition to trace element data. Anal Chem 44:2176-2180

Laplace G (1972) La typologie analytique et structurale: base rationelle d'études des industries lithiques et osseuses. Banques de Données Archéologiques, 932:91-143

Laplace G (1987) Un exemple de nouvelle écriture de la grille typologique. Dialktikê Cahiers de Typologie Analytique, 19851987:16-21

Luedtke B (1979) The indentification of sources of chert artifacts. Am Antiq 44(4):744-757

Maillo JM (2007) Aproximación tecnológica del final del Musteriense de Cueva Morín (Villanueva de Villaescusa, Cantabria, España). Munibe 58:13-42

Manzano I, Baena J, Lázaro A, Martín D, Dapena L, Roca M et al (2005) Análisis de los recursos líticos en la Cueva del Esquilleu: gestión y 
comportamiento durante el Musteriense (Comarca de la Liébana, Occidente de Cantabria). In: Montes R, Lasheras JA (eds) Actas de la reunión científica: Neandertales cantábricos, estado de la cuestión. Celebrada en el Museo de Altamira los días 20-22 de Octubre de 2004. Ministerio de Educación y Cultura, Madrid, pp 285-300

Meignen L, Delagnes A, Bourguignon L (2009) Patterns of lithic material procurement and transformation during the Middle Paleolithic in Western Europe, Lithic Materials and Paleolithic Societies, WileyBlackwell, pp 15-24

Morala A (1980) Observations sur le Périgordien et l'Aurignacien et leurs matieéres premiéres lithiques en Haute-Agenais. Dissertation, Université de Toulouse

Pelayo López F, Gonzalo Gutiérrez R (2012) Juan Vilanova y Piera (1821-1893), la obra de un naturalista y prehistoriador valenciano. Diputación de Valencia, Valencia

Pitblado B, Deheler C, Neff H, Nelson S (2008) Pilot study experiments sourcing quartzite, Gunnison Basin. Geoarcheology 23(6):741-778

Pitblado B, Cannon M, Neff H, Dehler C, Nelson S (2012) LA-ICP-MS analysis of quartzite from the Upper Gunnison Basin, Colorado. J Archaeol Sci 40:2196-2216

Polanyi K (1957) The economy as instituted process. In: Polanyi K, Arensberd C, Pearson $\mathrm{H}$ (eds) Trade and market in the early empires. Free Press, New York, pp 243-270

Prieto A, Yusta I, Arrizabalaga A (2019) Defining and characterizing archaeological quartzite: sedimentary and metamorphic processes in the lithic assemblages of El Habario and El Arteu (Cantabrian Mountains, Northern Spain). Archaeometry 61(1):14-30. https:// doi.org/10.1111/arcm.12397

Richter J (2016) Leave at the height of the party: a critical review of the Middle Paleolithic in Western Central Europe from its beginnings to its rapid decline. Quat Int 411:107-128. https://doi.org/10.1016/j. quaint.2016.01.018

Rios-Garaizar J (2010) Organización económica de las sociedades neandertales: el caso del nivel VII de Amalda (Zestoa, Gipuzkoa). Zéphyrus 65:15-37

Rios-Garaizar J (2012) Industria lítica y sociedad del Paleolítico medio al superior en torno al Golfo de Bizkaia. Publican-Ediciones de la Universidad de Cantabria, Santander

Roebroeks W (1988) From find scatters to early hominid behaviour: a study of middle Palaeolithic riverside sttlements at MaastrichBelvédere (the Neanderlands). Sidestone Press, Leiden

Romagnoli F, Nishiaki Y, Rivals F, Vaquero M (2018) Time uncertainty, site formation processes, and human behaviours: new insights on old issues in High-Resolution Archaeology. Quat Int 474(Part B): 99-102. https://doi.org/10.1016/j.quaint.2018.04.033

Roy M, Mora R, Plasencia FJ, Martínez-Moreno J, Benito-Calvo A (2017) Quartzite selection in fluvial deposits: the N12 level of Roca dels Bous (Middle Palaeolithic, southeastern Pyrenees). Quat Int 435:49-60. https://doi.org/10.1016/j.quaint.2015.09.010
Santamaría D, Fortea J, De La Rasilla M, Martínez L, Martínez E, Cañaveras JC et al (2010) The technological and typological behaviour of a neanderthal group from el. Sidrón Cave (Asturias, Spain) 29(2):119-148. https://doi.org/10.1111/j.1468-0092.2010.00342.x

Sarabia P (2000) Aprovechamiento y utilización de las materias primas líticas en los tecnocomplejos del Paleolítico en Cantabria. Dissertation, Universidad de Santander

Séronie-Vivien, M, Séronie-Vivien, M-R (1987) Les silex du Mésozoïque nord-aquitain. Approche géologique de l'étude des silex pour servir à la recherche préhistorique. Bulletin de la Société Linnéenne de Bordeaux, Suppl. XV:136

Sieveking G, Bush P, Ferguson J, Craddock PT, Hughes MJ, Cowell MR (1972) Prehistoric flint mines and their identication as sources of raw material. Archaeometry 14(2):151-176

Singer CA, Ericson J (1977) Quarry analysis at Bodie Hilles, Mono County, Californa: a case study. In: Earle T, Ericson J (eds) Exchange systems in prehistory. Academic Press, New York, pp 91-108

Skolnick H (1965) The quarzite problem. J Sediment Petrol 35(1):12-21

Turq A (1996) L'approvisionnement en matiere premiere lithique au Mousterien et au début du Paléolithique supérieur dans le nord est du bassin aquitain: Continuité ou discontinuité. In: Carbonell E, Vaquero M (eds) The Last Neandertals The First Anatomically Modern Humans. Fundació catalana per a la recerca, pp 355-362

Turq A, Roebroeks W, Bourguignon L, Faivre J-P (2013) The fragmented character of middle Palaeolithic stone tool technology. J Hum Evol 65(5):641-655. https://doi.org/10.1016/j.jhevol.2013.07.014

Turq A, Faivre J-P, Gravina B, Bourguignon L (2017) Building models of Neanderthal territories from raw material transports in the Aquitaine Basin (southwestern France). Quat Int 433(Part B):88-101. https:// doi.org/10.1016/j.quaint.2016.02.062

Vaquero M, Romagnoli F (2017) Searching for lazy people: the significance of expedient behavior in the interpretation of Paleolithic assemblages. J Archaeol Method Theory 25:334-367. https://doi.org/ 10.1007/s10816-017-9339-x

Veldeman I, Baele JM, Goemaere E, Deceukelaire M, Dusar M, De Doncker H (2012) Characterizing the hypersiliceous rocks of Belgium used in (pre-)history: a case study on sourcing sedimentary quartzites. J Geophys Eng 9:118-128

Wentworth CK (1922) A scale of grade and class terms for clastic sediments. J Geol 30:377-392

Wilson CJL (1973) The prograde microfabric in a deformed quartzite sequence, Mount Isa, Australia. Tectonophysics 19(1):39-81. https://doi.org/10.1016/0040-1951(73)90142-X

Publisher's note Springer Nature remains neutral with regard to jurisdictional claims in published maps and institutional affiliations. 